7th International Symposium on Superalloy 718 and Derivatives Edited by: E.A. Ott, J.R. Groh, A. Banik, I. Dempster, T.P. Gabb, R. Helmink, X. Liu, A. Mitchell, G.P. Sjöberg, and A. Wusatowska-Sarnek TMS (The Minerals, Metals \& Materials Society), 2010

\title{
LONG TERM THERMAL EXPOSURE OF HAYNES 282 ALLOY
}

\author{
L. M. Pike \\ Haynes International \\ 1020 West Park Ave.; Kokomo, IN, 46904-9013 USA
}

Keywords: 282 alloy, thermal stability, R-41 alloy, Waspaloy alloy, 263 alloy

\begin{abstract}
HAYNES ${ }^{\circledR} 282^{\circledR}$ alloy was recently introduced for applications in both aero and land-based gas turbine engines. While possessing excellent high temperature strength and LCF resistance, the alloy was designed to ensure adequate fabricability. The new alloy is readily hot and cold worked and has superior weldability relative to other alloys in its class. A key attribute of 282 alloy is the excellent stability of its microstructure upon long term thermal exposure. As a result, the alloy is not prone to severe embrittlement as are certain other alloys in its class. The stability of the alloy is also believed to contribute to the high temperature strength of the alloy over long exposure periods. In this paper, the thermal stability of 282 alloy will be investigated in two parts. The first being a comparative study of moderately long (1,000 hour) exposures between 282 alloy and other alloys in its class. The second part will investigate the effect of much longer thermal exposures of up to 16,000 hours on the tensile properties of 282 alloy.
\end{abstract}

\section{Introduction}

Thermal stability is a key feature of alloys intended for long-term service at elevated temperatures. For gamma-prime strengthened alloys in particular, there are two main issues which can arise due to microstructural instability: loss of ductility and loss of strength. Both issues can be problematic for components constructed from materials of poor thermal stability. A loss of ductility is often associated with the formation of secondary phases. If these secondary phases are deleterious in nature, such the TCP-type sigma, Laves, or mu phases, significant embrittlement can occur. This embrittlement is more often seen at room temperature (RT) than at elevated temperatures (ET). Loss of strength can arise in these types of alloys due to a number of reasons, including gamma-prime coarsening and/or dissolution as well as formation of TCPtype phases which can deprive the matrix of critical elements such as Mo.

Little data has been published to date on the thermal stability of HAYNES 282 alloy [1,2]. The present study will provide more insight on this topic in two main parts. The first will focus on moderately long (1,000 hour) thermal exposures of 282 alloy in comparison to other alloys in its class: R-41 (René 41) alloy, Waspaloy alloy, and 263 alloy. The effects of thermal exposure on both tensile properties and microstructural features will be presented. The second part of the study will focus on longer term exposures of up to 16,000 hours on the tensile properties of 282 alloy.

HAYNES, 282, and 230 are registered trademarks of Haynes International 


\section{Experimental}

For the first part of the study, samples of 282 alloy, R-41 alloy, Waspaloy alloy, and 263 alloy were taken from $0.063 "(1.6 \mathrm{~mm})$ thick production sheet material in the mill annealed condition. The nominal compositions of these alloys are given in Table I. The samples were age-hardened according to typical heat treatment specifications for the particular alloy: 282 alloy, $1850^{\circ} \mathrm{F}$ $\left(1010^{\circ} \mathrm{C}\right) / 2 \mathrm{~h} / \mathrm{AC}+1450^{\circ} \mathrm{F}\left(788^{\circ} \mathrm{C}\right) / 8 \mathrm{~h} / \mathrm{AC} ; \mathrm{R}-41$ alloy, $2050^{\circ} \mathrm{F}\left(1121^{\circ} \mathrm{C}\right) / 0.5 \mathrm{~h} / \mathrm{RAC}+1650^{\circ} \mathrm{F}$ $\left(899^{\circ} \mathrm{C}\right) / 4 \mathrm{~h} / \mathrm{AC}$; Waspaloy alloy, $1825^{\circ} \mathrm{F}\left(996^{\circ} \mathrm{C}\right) / 2 \mathrm{~h} / \mathrm{AC}+1550^{\circ} \mathrm{F}\left(843^{\circ} \mathrm{C}\right) / 4 \mathrm{~h} / \mathrm{AC}+1400^{\circ} \mathrm{F}$ $\left(760^{\circ} \mathrm{C}\right) / 16 \mathrm{~h} / \mathrm{AC} ; 263$ alloy, $1472^{\circ} \mathrm{C}\left(800^{\circ} \mathrm{C}\right) / 8 \mathrm{~h} / \mathrm{AC}$. Samples were subjected to 1000 -hour thermal exposures at $1200^{\circ} \mathrm{F}\left(649^{\circ} \mathrm{C}\right), 1400^{\circ} \mathrm{F}\left(760^{\circ} \mathrm{C}\right), 1500^{\circ} \mathrm{F}\left(816^{\circ} \mathrm{C}\right)$, and $1600^{\circ} \mathrm{F}\left(871^{\circ} \mathrm{C}\right)$. The exposures were conducted in a still air environment. Tensile tests were conducted on the thermally exposed material at room temperature as well as at the exposure temperature (all tensile testing in this study was performed on duplicate samples). For baseline reference, tensile testing was also performed on material in the as-heat treated (as-HT) condition. All tensile samples were oriented in the direction transverse to the rolling direction of the sheet. Flat tensile samples were machined from the sheet material with the sample surface remaining in the asoxidized condition. The tensile properties of thermally exposed 282 alloy, R-41 alloy, Waspaloy alloy, and 263 alloy are given in Table 1 along with the tensile properties in the original as-heat treated condition. These results will be discussed in more detail in the next section of this manuscript. Optical microscopy was performed on as-exposed material using an electrolytic oxalic/hydrochloric acid etch. Additionally, thermally exposed samples were examined using a $\mathrm{SEM} / \mathrm{EDS}$ system. Samples were given an electrolytic etch $\left(15 \mathrm{~g} \mathrm{CrO}_{3}, 150 \mathrm{~mL} \mathrm{H}_{3} \mathrm{PO}_{4}, 10 \mathrm{~mL}\right.$ $\mathrm{H}_{2} \mathrm{SO}_{4}$ ) to reveal the gamma-prime structure.

For the second part of the study, samples of 282 alloy were taken from $1 / 2^{\prime \prime}(12.7 \mathrm{~mm})$ thick production plate material obtained in the mill annealed condition. The samples were heat treated in the same manner as the first part of this study. Samples were then subjected to 100, 1000, 4000,8000 , and 16000 hour exposures at $1200^{\circ} \mathrm{F}\left(649^{\circ} \mathrm{C}\right), 1400^{\circ} \mathrm{F}\left(760^{\circ} \mathrm{C}\right)$, and $1600^{\circ} \mathrm{F}$ $\left(871^{\circ} \mathrm{C}\right)$. Round tensile samples (transverse to the rolling direction) were machined from the plate material such that the oxidized surfaces had been completely machined away. Duplicate tensile tests were conducted on the as-heat treated and the thermally exposed samples.

\section{Results and Discussion}

Part One: Comparative Thermal Stability Study

A comparative study of moderately long (1,000 hour) thermal exposures was conducted on 282 alloy along with other alloys in its class: R-41 alloy, Waspaloy alloy, and 263 alloy. The effects of thermal exposure on both tensile properties and microstructural features are discussed.

Room Temperature Tensile. The RT tensile elongation is shown in Fig. 1a as a function of exposure temperature. (Note that for this plot, and analogous plots in this manuscript, the properties for the "RT exposed" samples are simply taken as the properties in the as-HT condition.) For 282 alloy the RT tensile elongation was found to decrease only mildly after thermal exposure, starting out at $31 \%$ in the as-HT condition and dropping to a low of $21 \%$ after the 1000-hour exposure at $1500^{\circ} \mathrm{F}$ - the exposure temperature resulting in the greatest loss in ductility. In a similar fashion, both Waspaloy alloy and 263 alloy were found to retain very respectable RT elongation after the 1000-hour thermal exposures. For 263 alloy, the elongation started out at $33 \%$, dropped to $21 \%$ for the $1200^{\circ} \mathrm{F}$ thermal exposure, and then increased with increasing exposure temperature to a high of $41 \%$ for the $1600^{\circ} \mathrm{F}$ exposure. In contrast, the RT 
elongation of Waspaloy started at $24 \%$ in the as-HT condition and remained fairly constant with exposure temperature, dropping only to $18 \%$ for the $1600^{\circ} \mathrm{F}$ exposure. The alloy showing the greatest effect of thermal exposure was R-41 alloy, where the RT elongation dropped sharply for all exposure temperatures. With an initial value at $19 \%$, the elongation dropped to $8.9 \%$ for the $1200^{\circ} \mathrm{F}$ exposure and to levels around $2 \%$ for exposures between 1400 and $1600^{\circ} \mathrm{F}$.

The RT yield strength of the 1000-hour thermally exposed samples is shown in Fig. 1b as a function of exposure temperature. The yield strength of 282 alloy in the as-HT condition was $100.5 \mathrm{ksi}$; it increased to $112.9 \mathrm{ksi}$ after the $1200^{\circ} \mathrm{F}$ exposure; likewise, it was also greater than in the as-HT condition after the $1400^{\circ} \mathrm{F}$ exposure $(104.1 \mathrm{ksi})$. On the other hand, the thermal exposure of 282 alloy at $1500^{\circ} \mathrm{F}$ led to a modest drop in yield strength $(91.9 \mathrm{ksi})$. The thermal exposure at $1600^{\circ} \mathrm{F}$ led to a more significant drop in yield strength, resulting in a value of 72.9 ksi after the 1000-hour period. The RT yield strengths of Waspaloy and R-41 alloys were greater than 282 alloy in the as-HT condition due to higher gamma-prime content. This was also true for samples thermally exposed at $1200^{\circ} \mathrm{F}$ which resulted in slightly higher yield strengths for both alloys. For samples thermally exposed at $1400^{\circ} \mathrm{F}$, the two alloys differed significantly. R41 alloy was found to further strengthen at this temperature, while Waspaloy alloy suffered a drop in strength. In fact, of the four alloys in this study, only Waspaloy was found to lose RT strength after the 1000 -hour exposure at $1400^{\circ} \mathrm{F}$. The yield strength of R-41 alloy and Waspaloy alloy decreased with further increases in exposure temperature. The RT yield strength of 263 alloy was the lowest of the four alloys. After the $1200^{\circ} \mathrm{F}$ exposure, the yield strength increased slightly, while after the $1400^{\circ} \mathrm{F}$ exposure it was virtually unaffected. Thermal exposures of 1500 and $1600^{\circ} \mathrm{F}$ resulted in significant drops in yield strength for 263 alloy.

Elevated Temperature Tensile. Of more interest than the RT tensile properties in determining the in-service effects of thermal exposure are the elevated temperature tensile properties at the exposure temperature itself. The tensile elongation at the exposure temperature is shown in Fig. 2a. For 282 alloy, Waspaloy alloy, and 263 alloy, the ET elongations were all very high, being around $25 \%$ or higher for all exposure temperatures. In contrast, the R-41 alloy did exhibit a low elongation value as a result of thermal exposure, but only for the case of the $1200^{\circ} \mathrm{F}$ exposure. In this case, the $1200^{\circ} \mathrm{F}$ ductility was only $11 \%$ after the thermal exposure. For higher thermal exposures, the elongation of R-41 alloy was greater than $25 \%$.

The yield strength at the exposure temperature is plotted in Fig. $2 \mathrm{~b}$ as a function of the exposure temperature. After a $1200^{\circ} \mathrm{F}$ exposure, the $1200^{\circ} \mathrm{F}$ yield strength of the R-41 alloy and Waspaloy alloy was significantly higher than 282 alloy and 263 alloy. However, after a $1400^{\circ} \mathrm{F}$ exposure the situation was quite different. In this case, the $1400^{\circ} \mathrm{F}$ yield strength of Waspaloy significantly dropped, particularly in comparison to 282 alloy. After thermal exposure in the range of 1400 to $1600^{\circ} \mathrm{F}, 282$ alloy was found to have a higher yield strength at the exposure temperature than Waspaloy, which in turn was stronger than 263 alloy. Only R-41 alloy had higher strength after thermal exposure in this range than 282 alloy.

Another way to consider the effects of thermal exposure on the yield strength is shown in Fig. 3 where the yield strength of the four alloys is shown before and after thermal exposure. For thermal exposures at $1200^{\circ} \mathrm{F}$, the yield strength of all four alloys was found to increase as a result of the thermal exposure. However, thermal exposures of $1400^{\circ} \mathrm{F}$ resulted in a decrease in the yield strength for three of the alloys: R-41 alloy, Waspaloy alloy, and 263 alloy. Only 282 alloy was found to increase in strength after the $1400^{\circ} \mathrm{F}$ thermal exposure. The yield strength of all four alloys was found to decrease after thermal exposures at 1500 and $1600^{\circ} \mathrm{F}$, with the 
decreases generally more severe in the latter case. Explanations for the observed effects of thermal exposure on the mechanical properties can be tied to changes in the microstructure as will be discussed later in this manuscript.

Microstructural Stability. Optical micrographs of thermally exposed 282 alloy, R-41 alloy, Waspaloy alloy, and 263 alloy are presented in Figs. 4-7. For each alloy, four micrographs are shown which correspond to 1000 -hour exposures at 1200, 1400, 1500, and $1600^{\circ} \mathrm{F}$. For 282 alloy little difference can be seen between the various exposure temperatures. No evidence of deleterious phases can be seen. In contrast, for R-41 alloy significant intragranular precipitation can be seen for thermal exposures between 1400 and $1600^{\circ} \mathrm{F}$. Previous investigators have reported the presence of mu phase and sigma phase in thermally exposed R-41 alloy [3,4]. For 263 alloy there is no evidence of deleterious phase formation except after the $1600^{\circ} \mathrm{F}$ exposure. In this case, plate-like precipitates can be observed. These are likely the eta phase $\left(\mathrm{Ni}_{3} \mathrm{Ti}\right)$ which has been reported in thermally exposed 263 alloy [5,6]. For Waspaloy alloy, the optical micrographs do not differ significantly between exposure temperatures and no evidence of deleterious phases was observed. (Note that the magnification of the optical micrographs is insufficient to resolve the gamma-prime phase.)

To resolve the effect of thermal exposure on the gamma-prime phase it is necessary to use an SEM. Such SEM images for the four alloys in this study are shown in Figs. 8, 9, 10, and 11 for 1000 -hour thermal exposures of $1200,1400,1500$, and $1600^{\circ} \mathrm{F}$, respectively. For the $1200^{\circ} \mathrm{F}$ exposure, the gamma-prime precipitates did not increase much in size compared to the as-HT condition (not shown). The 282 and 263 alloys had smaller gamma-prime precipitates relative to R-41 and Waspaloy alloys, which is believed to be a result more of their original heat treatment conditions than the $1200^{\circ} \mathrm{F}$ thermal exposure itself. After the $1400^{\circ} \mathrm{F}$ exposure, the gammaprime precipitates were observed to coarsen somewhat for all four alloys, and were homogeneously distributed (as they also had been in the as-HT and $1200^{\circ} \mathrm{F}$ exposed samples). For exposures at $1500^{\circ} \mathrm{F}$, the gamma-prime precipitates coarsened more for all four alloys. The gamma-prime was again homogenously distributed, except for 263 alloy where the gammaprime could be seen to be aligning along preferred directions. After the $1600^{\circ} \mathrm{F}$ exposure, considerable coarsening was seen in all four alloys. For 282 alloy, Waspaloy alloy, and 263 alloy the gamma-prime precipitates appeared to be adopting a somewhat cuboidal shape, while for R-41 alloy these remained spherical. In 263 alloy, the volume fraction of the gamma-prime phase was considerably lower after the $1600^{\circ} \mathrm{F}$ exposure than for the other exposure temperatures.

The phases depicted in Figs. 8-11 were mostly gamma-prime and secondary grain boundary carbides. Also seen in a few images (e.g. Fig. 8b) were large primary carbides. For 282 alloy and Waspaloy alloy, no additional phases were observed for any of the exposure temperatures. In R-41 alloy exposed at temperatures between 1400 and $1600^{\circ} \mathrm{F}$, certain large intragranular phases (mu and possibly sigma) can be seen throughout the microstructure, consistent with the optical micrographs in Fig. 5. Finally, in thermally exposed 263 alloy, a small amount of a eta phase was observed in the images, particularly for samples exposed at $1500^{\circ} \mathrm{F}$.

A limited SEM/EDS analysis of precipitate phases was conducted on the four alloys in the as-HT condition as well as after the 1000 -hour exposure at $1400^{\circ} \mathrm{F}$. The results are given in Table 3 and backscatter images taken of the samples are shown in Fig. 12. The primary phases TiN and $\mathrm{MC}$ were found in all four alloys. In R-41 alloy, the $\mathrm{M}_{6} \mathrm{C}$ phase was also identified as a primary precipitate. Secondary $\mathrm{M}_{23} \mathrm{C}_{6}$ carbides were found in all four alloys predominantly along grain 
boundaries. Additionally, secondary $\mathrm{M}_{6} \mathrm{C}$ carbides were observed in 282 alloy and R-41 alloy. In addition to the gamma-prime phase observed in all samples, the eta and mu phases were observed in 263 alloy and R-41 alloy, respectively, after the 1000-hour exposure. No sigma phase was identified in the thermally exposed R-41 sample (as has been found previously [4]), but an exhaustive search for the sigma phase was not conducted in the present study.

Correlation of Microstructure/Tensile Properties. The residual tensile properties of the thermally exposed alloys can be correlated to certain microstructural features. For example, the high elongation of thermally exposed 282 alloy, Waspaloy alloy, and 263 alloy at both RT and the exposure temperature (Figs. 1a and 2a) can be attributed to the lack of significant formation of deleterious phases. In the case of 263 alloy, the fairly small amount of eta phase was apparently not enough to result in significant embrittlement. A future study would be to look at longer thermal exposures of 263 alloy to determine if further precipitation of the eta phase would lead to loss of ductility. For R-41 alloy, the drop in both RT and ET temperature ductility in samples thermally exposed at temperatures between 1400 and $1600^{\circ} \mathrm{F}$ can be attributed to the precipitation of mu phase (and possibly sigma phase).

The effect of microstructure on the yield strength of these thermally exposed alloys is somewhat complicated and can depend on gamma-prime size and volume fraction, the presence of deleterious phases, etc. Generally, the yield strength will decrease if the exposure temperature for a given alloy results in gamma-prime "overaging" and/or loss of phase fraction. An example is the case of 263 alloy exposed at $1600^{\circ} \mathrm{F}$ for 1,000 hours. The yield strength may also decrease as a result of deleterious phase formation. In R-41 alloy, mu-phase formation results in a loss of strength when tested at the exposure temperature, but this effect is apparently not seen when tested at RT (see Figs. $2 \mathrm{a}$ and $2 \mathrm{~b}-1400^{\circ} \mathrm{F}$ exposure).

Part Two: Long Term (16,000-hour) Thermal Exposures - 282 alloy

The present manuscript details the tensile properties of 282 alloy exposed for up to 16,000 hours. A thorough examination of the resulting microstructures will be presented elsewhere [7]. Please note that corresponding tests for R-41, Waspaloy, and 263 alloy were not part of the present study.

Room Temperature Tensile. The RT elongation of 282 alloy is shown in Fig. 13a as a function of exposure duration. In the as-HT condition the RT elongation was $30 \%$. When exposed at $1200^{\circ} \mathrm{F}$, the elongation dropped to $27 \%$ after 100 hours. Longer thermal exposures led to only very gradual further decreases in elongation, and after 16,000 hours the elongation was still $23 \%$. The largest drops in RT elongation were observed in samples exposed at $1400^{\circ} \mathrm{F}$. When exposed at this temperature, the elongation dropped with increasing exposure duration out to about 4,000 hours. At this point the elongation was $21 \%$. The elongation was essentially constant with further thermal exposure at $1400^{\circ} \mathrm{F}$, only dropping to $20 \%$ after the full 16,000 hour exposure. For $1600^{\circ} \mathrm{F}$ exposures the RT elongation was virtually independent of exposure duration, increasing only very slightly from $30 \%$ to $33 \%$ after 16,000 hours.

The RT yield strength is shown in Fig. 13b as a function of exposure duration. In the as-HT condition the yield strength was $102.3 \mathrm{ksi}$. Thermal exposure at $1200^{\circ} \mathrm{F}$ resulted in an increase in the yield strength. After 100 hours the yield strength was $115.8 \mathrm{ksi}$; it remained essentially constant after that, falling in the range of 118 to $120 \mathrm{ksi}$ for exposures between 1,000 and 16,000 hours. For exposures at $1400^{\circ} \mathrm{F}$, the yield strength initially increased as had been observed for 
the sheet material in Part One above. At longer exposure times the yield strength decreased gradually with increasing exposure, but retained a high level even after the full exposure duration. After 16,000 hours, the RT yield strength was still $95.5 \mathrm{ksi}-$ a value $93 \%$ of the original strength. For the $1600^{\circ} \mathrm{F}$ exposure the yield strength dropped with increasing exposure duration out to 4,000 hours, reaching a level of $70.7 \mathrm{ksi}$. However, with continued thermal exposure the yield strength was fairly constant, dropping only to $65.5 \mathrm{ksi}$ after the full 16,000 hours.

Elevated Temperature Tensile. As was done in Part One of this study, the elevated temperature tensile properties were characterized by testing at the exposure temperature. The ET elongation of thermally exposed 282 alloy is shown in Fig. $14 \mathrm{a}$. For $1200^{\circ} \mathrm{F}$ exposures, the $1200^{\circ} \mathrm{F}$ elongation dropped from $32 \%$ to $26 \%$ after 100 hours, but only slightly after that, reaching $23 \%$ after 16,000 hours. For both $1400^{\circ} \mathrm{F}$ and $1600^{\circ} \mathrm{F}$ thermal exposures, the ET elongation increased with exposure duration. In both cases, the largest increase occurred within the first 1,000 hours of exposure, with only gradual increases with further thermal exposure.

The ET yield strength is shown in Fig. $14 \mathrm{~b}$. At $1200^{\circ} \mathrm{F}$, the yield strength increased from 93.3 ksi to $103.1 \mathrm{ksi}$ after 100 hours and increased only very slightly with continued exposure duration. After 16,000 hours a value of $107.2 \mathrm{ksi}$ was reached. The $1400^{\circ} \mathrm{F}$ yield strength after exposure at $1400^{\circ} \mathrm{F}$ increased from $91.7 \mathrm{ksi}$ to $98.5 \mathrm{ksi}$ after 1,000 hours; continued exposure led to a modest drop in yield strength, eventually reaching a level of $79.2 \mathrm{ksi}$ after 16,000 hours - a value $86 \%$ of the original strength. For $1600^{\circ} \mathrm{F}$ exposures the yield strength at the exposure temperature dropped from $74.5 \mathrm{ksi}$ to $36.5 \mathrm{ksi}$ after 4,000 hours; longer exposures did not result in further loss of strength.

Implications for Long Term Service of 282 Alloy. The results of the thermal stability study of 282 alloy are very encouraging for applications involving long term service at elevated temperatures up to $1600^{\circ} \mathrm{F}$. The ductility of the alloy remains high, with RT and ET tensile elongations not falling below $\sim 20 \%$ even after exposures of 16,000 hours. The strength of 282 alloy also holds up well after thermal exposure. At $1200^{\circ} \mathrm{F}$, the RT and ET yield strengths increase with long term exposure. While the RT and ET yield strengths do eventually decrease somewhat after very long exposure times, they retain much of their original strength after the 16,000 hours (93\% and $86 \%$ for the RT and ET yield strengths, respectively). Despite this decrease, the yield strength of thermally exposed 282 alloy is still far superior to solid-solution strengthened alloys such as HAYNES $230^{\circledR}$ alloy [8] as shown in Fig. 15. Even at $1600^{\circ} \mathrm{F}$, where the yield strength of 282 alloy decreased the most, the retained RT and ET yield strengths are greater than those of 230 alloy. Furthermore, the yield strengths were found to have reached an essentially constant value between 4,000 and 16,000 hours at $1600^{\circ} \mathrm{F}$, suggesting that further degradation beyond 16,000 hours would very likely be insignificant.

\section{Summary and Conclusions}

1. The effect of thermal exposures on the tensile properties and microstructure of 282 alloy, R41 alloy, Waspaloy alloy, and 263 alloy in the range of 1200 to $1600^{\circ} \mathrm{F}$ was determined using 1,000 hour exposures. The behaviors of the four alloys were found to be quite different.

2. The retained yield strength of R-41 alloy was the highest of the four alloys for all exposure temperatures at both RT and ET, however, the alloy is subject to severe embrittlement when exposed at temperatures between 1400 and $1600^{\circ} \mathrm{F}$ due to the formation of deleterious phases. 
3. The other three alloys did not suffer embrittlement and with the exception of 263 alloy (eta phase), did not form deleterious phases within the 1,000 exposures at any temperature.

4. The retained yield strength at the exposure temperature of thermally exposed 282 alloy was higher than those of both Waspaloy alloy and 263 alloy after exposures at 1400 to $1600^{\circ} \mathrm{F}$.

5. Of the four alloys in the study, only 282 alloy was found to increase in strength after the 1,000 hour exposure at $1400^{\circ} \mathrm{F}$.

6. The thermal stability of 282 alloy was investigated using RT and ET tensile tests of materials exposed for up to 16,000 hours at temperatures between 1200 and $1600^{\circ} \mathrm{F}$. The results were very favorable for use in that temperature range in terms of both elongation and yield strength.

\section{Acknowledgements}

The efforts of laboratory technicians Mike Newburn, Rupinder Sharma, Mark Richeson, and John Cotner to produce the data in this paper are gratefully acknowledged.

\section{References}

1. L. M. Pike, "HAYNES 282 Alloy - A New Wrought Superalloy Designed for Improved Creep Strength and Fabricability", (Paper presented at ASME Turbo Expo 2006, Barcelona, Spain, May 8-11, 2006) Paper no. GT-2006-91204.

2. L. M. Pike, "Development of a Fabricable Gamma-Prime $(\gamma$ ') Strengthened Superalloy", (Paper presented at Superalloys 2008, Champion, PA, September 14-18, 2008) 191-200.

3. H. J. Beattie and W. C. Hagel, "Intergranular Precipitation of Intermetallic Compounds in Complex Austenitic Alloys," Trans. AIME, 221 (1961), 28-34.

4. H. E. Collins, "Relative Long-Time Stability of Carbide and Intermetallic Phases in Nickel-Base Superalloys", Trans. ASM, 62 (1969), 82-104.

5. W. Betteridge and J. Heslop, ed., The Nimonic Alloys (New York, NY: Crane, Russak \& Company, Inc. 1974), 86-7.

6. J.-C. Zhao, V. Ravikumar, and A. M. Beltran, "Phase Precipitation and Phase Stability in Nimonic 263," Metall. And Mater. Trans., 32A, (2001), 1271-82.

7. L. M. Pike, unpublished research.

8. L. M. Pike and S. K. Srivastava, "Thermal Stability of a Ni-Cr-W-Mo Alloy - Long-Term Exposures”, presented at Euro Superalloys Conference, May 25-28, 2010.

Table I Nominal Composition of Several Wrought Gamma-Prime Alloys (wt.\%)

\begin{tabular}{|c|c|c|c|c|c|c|c|c|c|c|c|c|}
\hline Alloy & Ni & Cr & Co & Mo & Ti & Al & Fe & Mn & Si & C & B & Other \\
\hline 282 & $57^{\mathrm{a}}$ & 20 & 10 & 8.5 & 2.1 & 1.5 & $1.5^{*}$ & $0.3^{*}$ & $0.15^{*}$ & 0.06 & 0.005 & -- \\
\hline Waspaloy & $58^{\mathrm{a}}$ & 19 & 13.5 & 4.3 & 3 & 1.5 & $2^{*}$ & $0.1^{*}$ & $0.15^{*}$ & 0.08 & 0.006 & $\mathrm{Zr}-0.05$ \\
\hline R-41 & $52^{\mathrm{a}}$ & 19 & 11 & 10 & 3.1 & 1.5 & $5^{*}$ & $0.1^{*}$ & $0.5^{*}$ & 0.09 & 0.006 & -- \\
\hline 263 & $52^{\mathrm{a}}$ & 20 & 20 & 6 & $2.4^{*}$ & $0.6^{*}$ & $0.7^{*}$ & 0.4 & 0.2 & 0.06 & 0.005 & $\mathrm{~A} 1+\mathrm{Ti}-2.6$ \\
\hline
\end{tabular}


Table II. Tensile properties* for the as-HT and thermally exposed (1000-hour) conditions

\begin{tabular}{|c|c|c|c|c|c|c|c|c|c|}
\hline \multirow{2}{*}{ Alloy } & \multicolumn{2}{|c|}{ Exposure Temp. } & \multicolumn{2}{|c|}{ Test Temp. } & \multicolumn{2}{|c|}{$0.2 \%$ YS } & \multicolumn{2}{|c|}{ UTS } & \multirow{2}{*}{$\begin{array}{c}\text { Elong. } \\
(\%)\end{array}$} \\
\hline & $\left({ }^{\circ} \mathbf{F}\right)$ & $\left({ }^{\circ} \mathrm{C}\right)$ & $\left({ }^{\circ} \mathrm{F}\right)$ & $\left({ }^{\circ} \mathrm{C}\right)$ & (ksi) & (MPa) & (ksi) & (MPa) & \\
\hline \multirow{13}{*}{$\begin{array}{c}282 \\
\text { alloy }\end{array}$} & \multirow{5}{*}{\multicolumn{2}{|c|}{$\begin{array}{c}\text { None } \\
\text { (As-HT) }\end{array}$}} & RT & RT & 100.5 & 693 & 163.5 & 1128 & 31 \\
\hline & & & 1200 & 649 & 88.2 & 608 & 143.7 & 991 & 27 \\
\hline & & & 1400 & 760 & 86.7 & 598 & 119.4 & 823 & 22 \\
\hline & & & 1500 & 816 & 79.9 & 551 & 98.2 & 677 & 19 \\
\hline & & & 1600 & 871 & 71.7 & 494 & 80.0 & 552 & 23 \\
\hline & 1200 & 649 & \multirow{4}{*}{ RT } & \multirow{4}{*}{ RT } & 112.9 & 778 & 172.8 & 1191 & 26 \\
\hline & 1400 & 760 & & & 104.1 & 718 & 170.5 & 1176 & 23 \\
\hline & 1500 & 816 & & & 91.9 & 634 & 159.8 & 1102 & 21 \\
\hline & 1600 & 871 & & & 72.9 & 502 & 141.4 & 975 & 24 \\
\hline & 1200 & 649 & 1200 & 649 & 98.6 & 680 & 150.4 & 1037 & 24 \\
\hline & 1400 & 760 & 1400 & 760 & 92.6 & 639 & 118.7 & 818 & 27 \\
\hline & 1500 & 816 & 1500 & 816 & 61.8 & 426 & 84.3 & 581 & 37 \\
\hline & 1600 & 871 & 1600 & 871 & 37.8 & 260 & 58.7 & 405 & 44 \\
\hline \multirow{13}{*}{$\begin{array}{l}\text { R-41 } \\
\text { alloy }\end{array}$} & \multirow{5}{*}{\multicolumn{2}{|c|}{$\begin{array}{c}\text { None } \\
\text { (As-HT) }\end{array}$}} & RT & RT & 113.8 & 785 & 179.2 & 1235 & 19 \\
\hline & & & 1200 & 649 & 108.2 & 746 & 174.1 & 1201 & 19 \\
\hline & & & 1400 & 760 & 112.7 & 777 & 139.6 & 962 & 27 \\
\hline & & & 1500 & 816 & 102.1 & 704 & 114.6 & 790 & 27 \\
\hline & & & 1600 & 871 & 78.5 & 541 & 89.1 & 614 & 23 \\
\hline & 1200 & 649 & \multirow{4}{*}{ RT } & \multirow{4}{*}{$\mathrm{RT}$} & 141.9 & 979 & 189.4 & 1306 & 8.9 \\
\hline & 1400 & 760 & & & 167.0 & 1151 & 197.2 & 1359 & 1.9 \\
\hline & 1500 & 816 & & & 137.9 & 951 & 177.5 & 1224 & 1.8 \\
\hline & 1600 & 871 & & & 103.8 & 715 & 148.0 & 1021 & 2.6 \\
\hline & 1200 & 649 & 1200 & 649 & 126.4 & 871 & 183.8 & 1267 & 11 \\
\hline & 1400 & 760 & 1400 & 760 & 104.1 & 718 & 137.5 & 948 & 26 \\
\hline & 1500 & 816 & 1500 & 816 & 64.8 & 447 & 98.0 & 675 & 34 \\
\hline & 1600 & 871 & 1600 & 871 & 42.0 & 290 & 69.2 & 477 & 37 \\
\hline \multirow{13}{*}{$\begin{array}{c}\text { Waspaloy } \\
\text { alloy }\end{array}$} & \multirow{5}{*}{\multicolumn{2}{|c|}{$\begin{array}{c}\text { None } \\
\text { (As-HT) }\end{array}$}} & RT & RT & 127.9 & 882 & 188.8 & 1301 & 24 \\
\hline & & & 1200 & 649 & 110.3 & 760 & 162.0 & 1117 & 34 \\
\hline & & & 1400 & 760 & 98.9 & 682 & 117.8 & 812 & 34 \\
\hline & & & 1500 & 816 & 73.8 & 509 & 91.0 & 628 & 38 \\
\hline & & & 1600 & 871 & 50.3 & 347 & 65.3 & 450 & 48 \\
\hline & 1200 & 649 & \multirow{4}{*}{ RT } & & 136.5 & 941 & 196.2 & 1353 & 23 \\
\hline & 1400 & 760 & & DT & 112.9 & 779 & 182.4 & 1258 & 24 \\
\hline & 1500 & 816 & & RI & 103.5 & 714 & 170.1 & 1173 & 23 \\
\hline & 1600 & 871 & & & 84.6 & 584 & 149.3 & 1030 & 18 \\
\hline & 1200 & 649 & 1200 & 649 & 120.4 & 830 & 168.4 & 1161 & 26 \\
\hline & 1400 & 760 & 1400 & 760 & 79.7 & 549 & 111.0 & 765 & 43 \\
\hline & 1500 & 816 & 1500 & 816 & 57.3 & 395 & 85.4 & 589 & 45 \\
\hline & 1600 & 871 & 1600 & 871 & 37.6 & 259 & 60.3 & 415 & 39 \\
\hline & & & RT & RT & 92.6 & 638 & 148.1 & 1021 & 33 \\
\hline & & & 1200 & 649 & 77.1 & 531 & 126.5 & 872 & 31 \\
\hline & & & 1400 & 760 & 78.5 & 541 & 100.5 & 693 & 27 \\
\hline & & & 1500 & 816 & 67.6 & 466 & 76.2 & 525 & 37 \\
\hline & & & 1600 & 871 & 41.1 & 283 & 49.0 & 338 & 50 \\
\hline & 1200 & 649 & & & 113.6 & 783 & 166.6 & 1149 & 21 \\
\hline $\begin{array}{l}263 \\
\text { allov }\end{array}$ & 1400 & 760 & PT & PT & 92.7 & 639 & 160.3 & 1105 & 32 \\
\hline & 1500 & 816 & RI & $\mathrm{RT}$ & 71.4 & 493 & 144.0 & 993 & 35 \\
\hline & 1600 & 871 & & & 55.0 & 379 & 125.2 & 863 & 41 \\
\hline & 1200 & 649 & 1200 & 649 & 96.1 & 663 & 144.1 & 993 & 29 \\
\hline & 1400 & 760 & 1400 & 760 & 73.3 & 505 & 95.0 & 655 & 34 \\
\hline & 1500 & 816 & 1500 & 816 & 45.9 & 316 & 64.9 & 448 & 45 \\
\hline & 1600 & 871 & 1600 & 871 & 27.2 & 187 & 42.7 & 295 & 54 \\
\hline
\end{tabular}

*Values represent an average of duplicate samples 
Table III. Phases Present in the as-HT and $1400^{\circ} \mathrm{F}\left(760^{\circ} \mathrm{C}\right) / 1000$-hour samples

\begin{tabular}{|c|c|c|c|c|}
\hline & 282 alloy & R-41 alloy & Waspaloy alloy & 263 alloy \\
\hline Primary & TiN & TiN & TiN & TiN \\
precipitates & $\mathrm{MC}$ & $\mathrm{MC}$ & $\mathrm{MC}$ & $\mathrm{MC}$ \\
& & $\mathrm{M}_{6} \mathrm{C}$ & $\mathrm{M}_{23} \mathrm{C}_{6}$ & $\mathrm{M}_{23} \mathrm{C}_{6}$ \\
\hline Secondary & $\mathrm{M}_{23} \mathrm{C}_{6}$ & $\mathrm{M}_{23} \mathrm{C}_{6}$ & & \\
carbides & $\mathrm{M}_{6} \mathrm{C}$ & $\mathrm{M}_{6} \mathrm{C}$ & & gamma-prime \\
& gamma-prime & gamma-prime & gamma-prime \\
Other secondary & mu & & sigma* \\
\hline
\end{tabular}

*Collins [4] - not confirmed in present study

Note: phases listed in italics were present only after the $1400^{\circ} \mathrm{F}\left(760^{\circ} \mathrm{C}\right)$ exposure
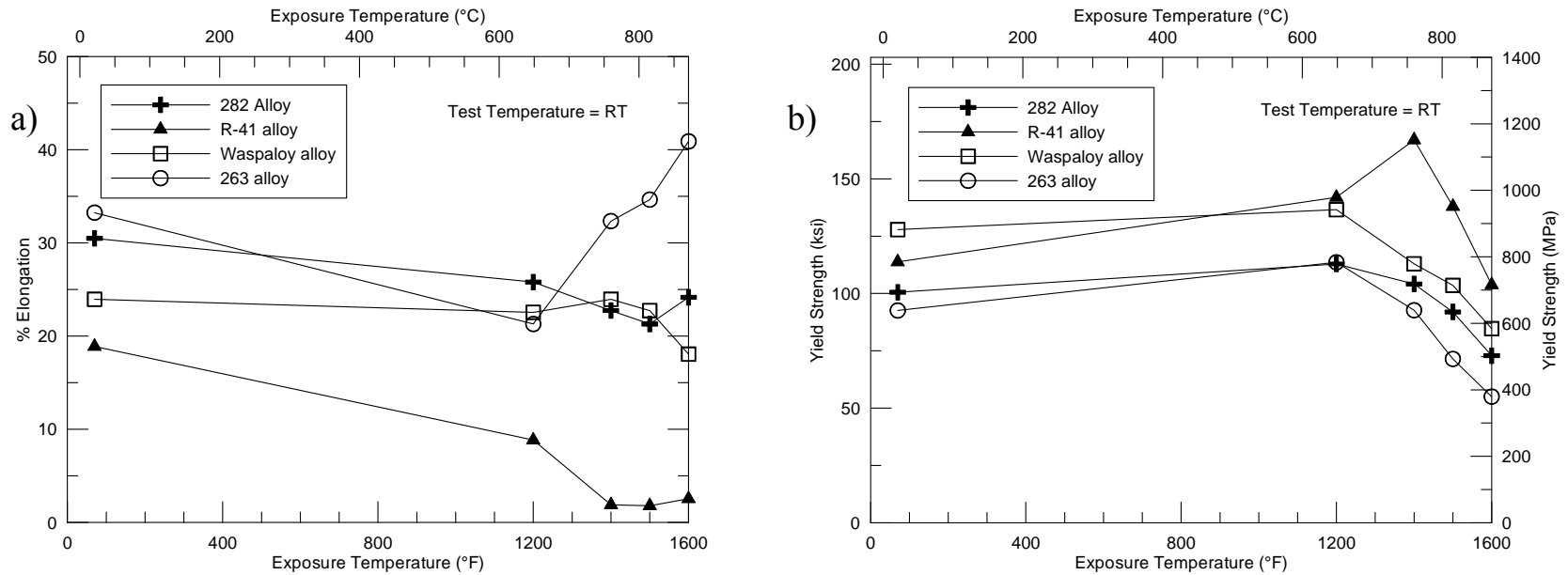

Fig. 1 Comparative RT tensile properties vs. thermal exposure temperature (1000-hour exposure).

a) elongation, b) yield strength
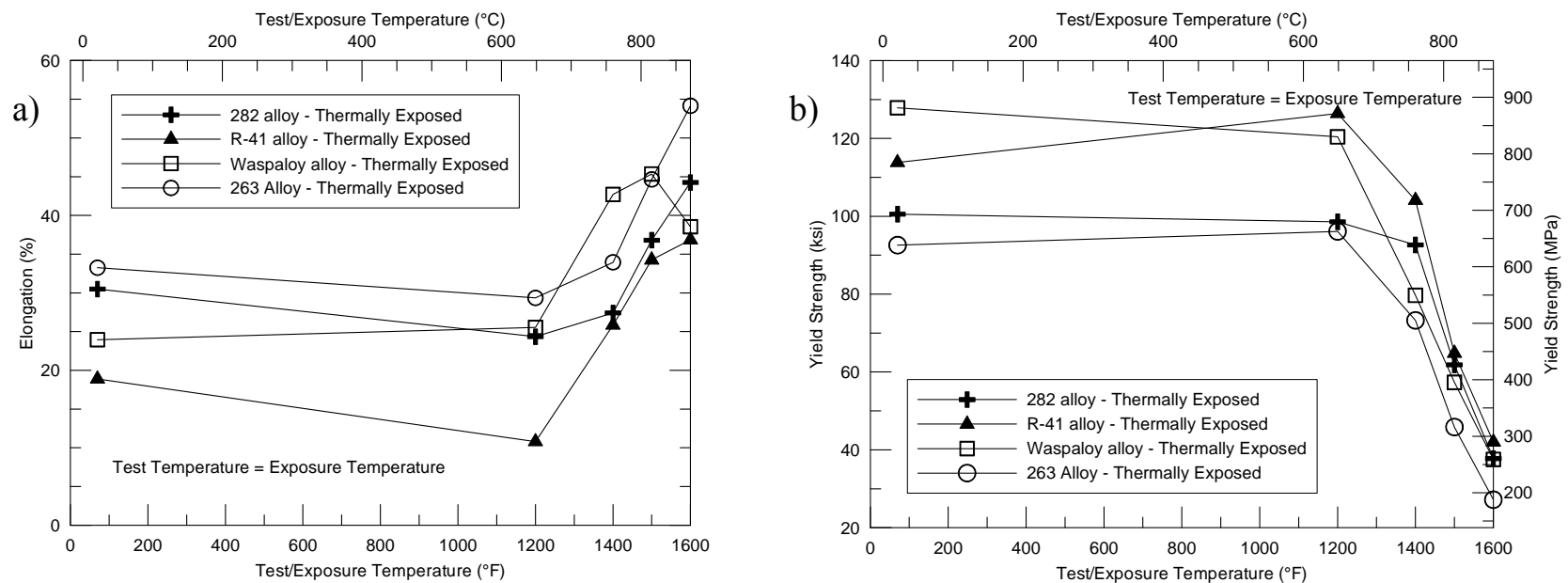

Fig. 2 Comparative ET tensile properties vs. thermal exposure temperature (1000-hour exposure). Tensile tests performed at the thermal exposure temperature. a) elongation, b) yield strength 


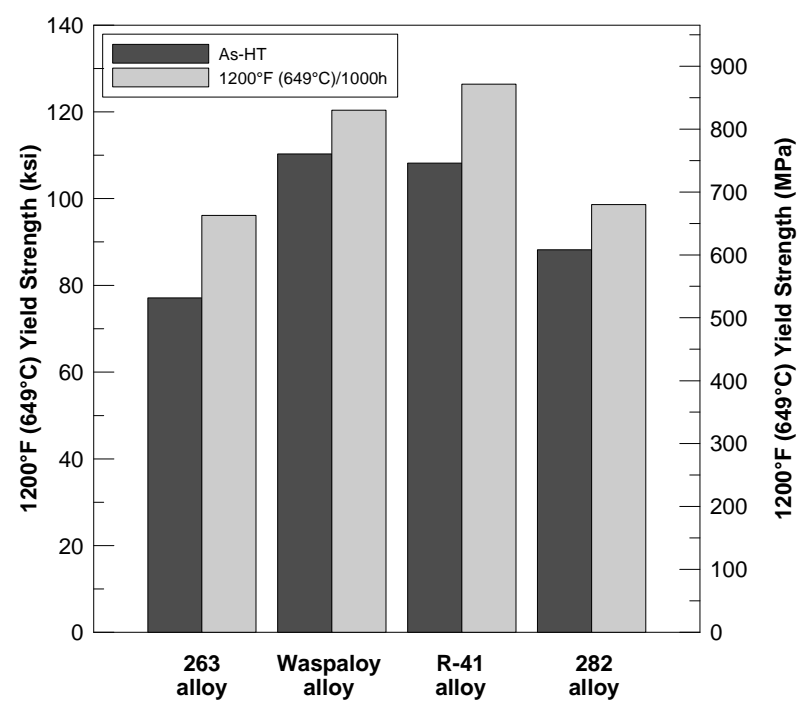

a)

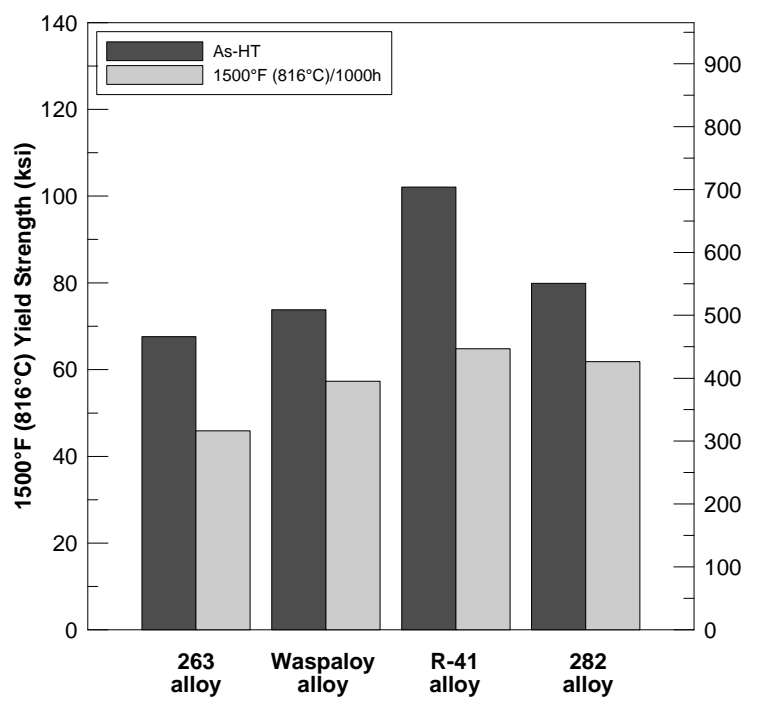

c)

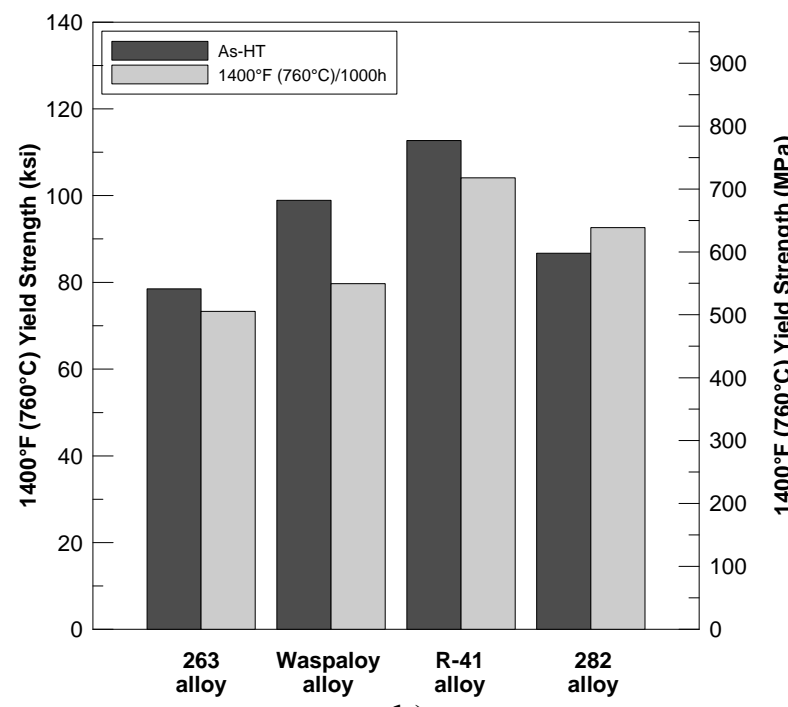

b)

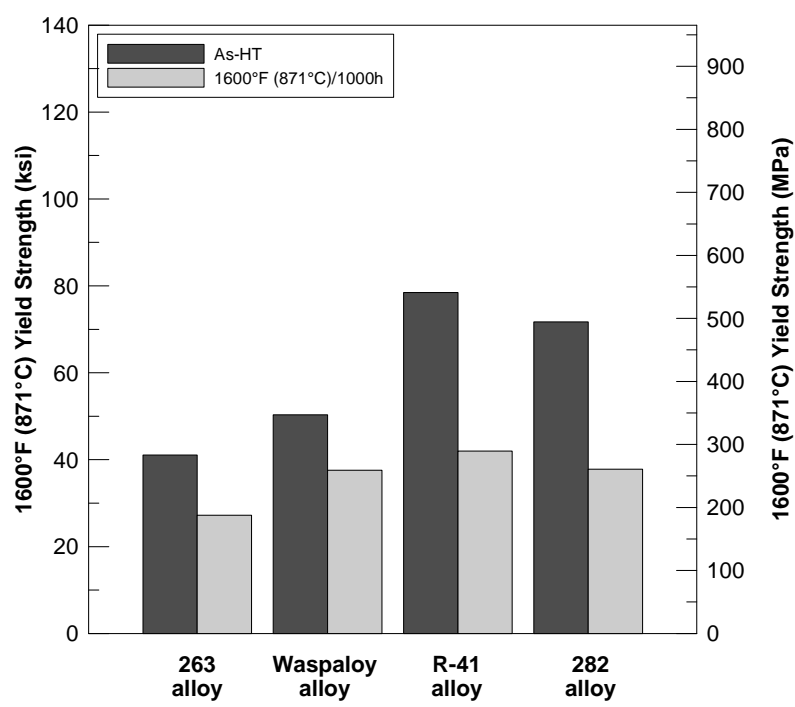

d)

Fig. 3 Comparative ET yield strength of the four alloys before and after 1000-hour thermal exposure. Tensile tests performed at the thermal exposure temperature. a) $1200^{\circ} \mathrm{F}\left(649^{\circ} \mathrm{C}\right)$, b) $1400^{\circ} \mathrm{F}\left(760^{\circ} \mathrm{C}\right)$, c) $1500^{\circ} \mathrm{F}\left(816^{\circ} \mathrm{C}\right)$, d) $1600^{\circ} \mathrm{F}\left(871^{\circ} \mathrm{C}\right)$. 
a)

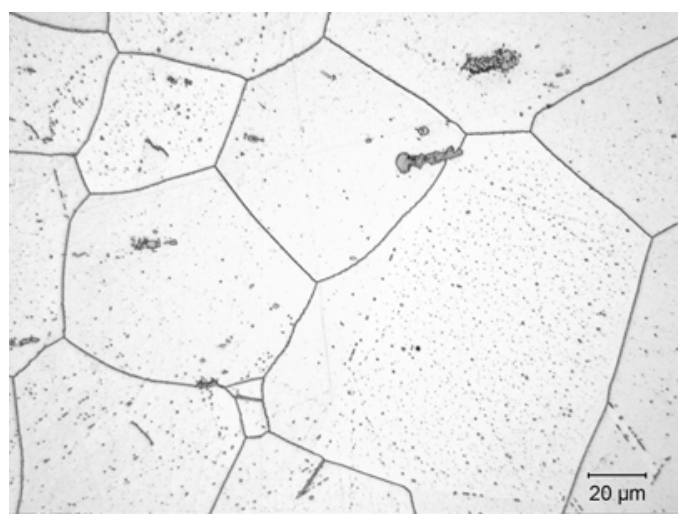

c)

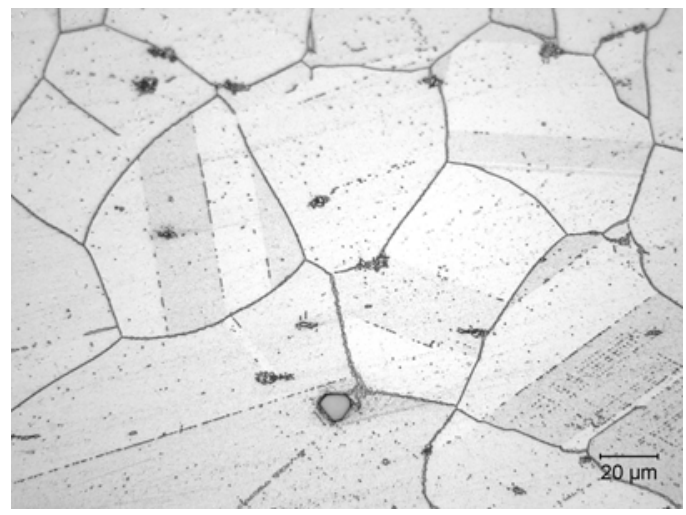

b)

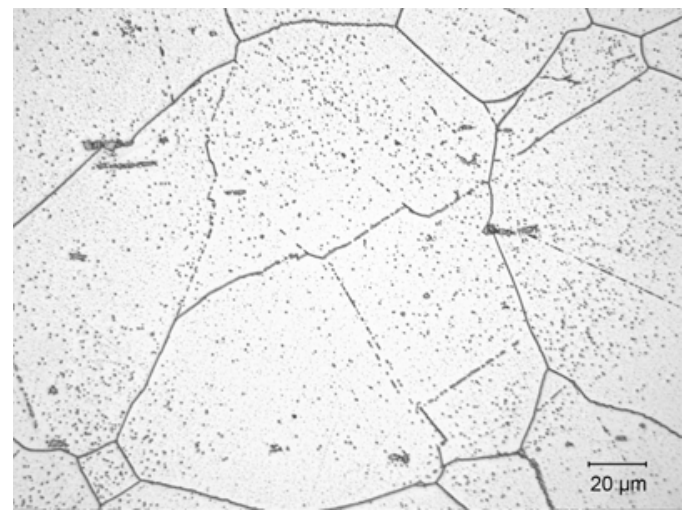

d)

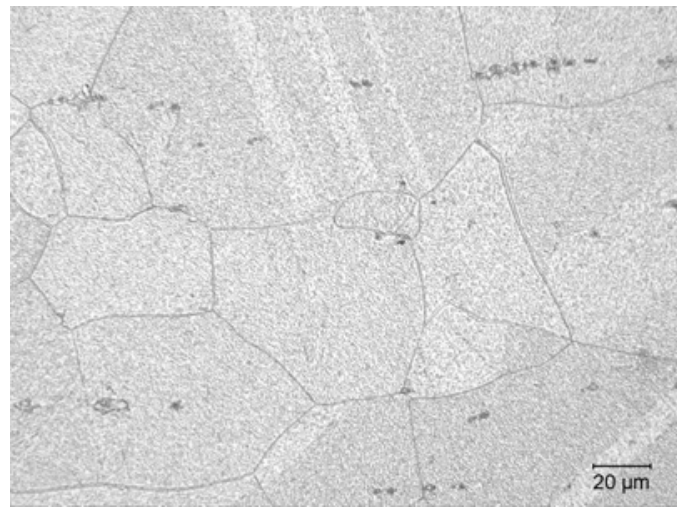

Fig. 4 Optical micrographs of thermally exposed 282 alloy (1000-hour exposure). a) $1200^{\circ} \mathrm{F}$ $\left.\left(649^{\circ} \mathrm{C}\right), \mathrm{b}\right) 1400^{\circ} \mathrm{F}\left(760^{\circ} \mathrm{C}\right)$, c) $1500^{\circ} \mathrm{F}\left(816^{\circ} \mathrm{C}\right)$, d) $1600^{\circ} \mathrm{F}\left(871^{\circ} \mathrm{C}\right)$.

a)

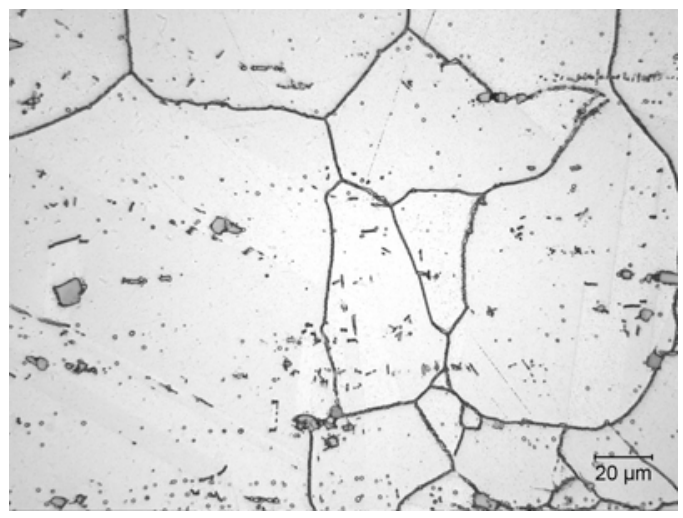

c)

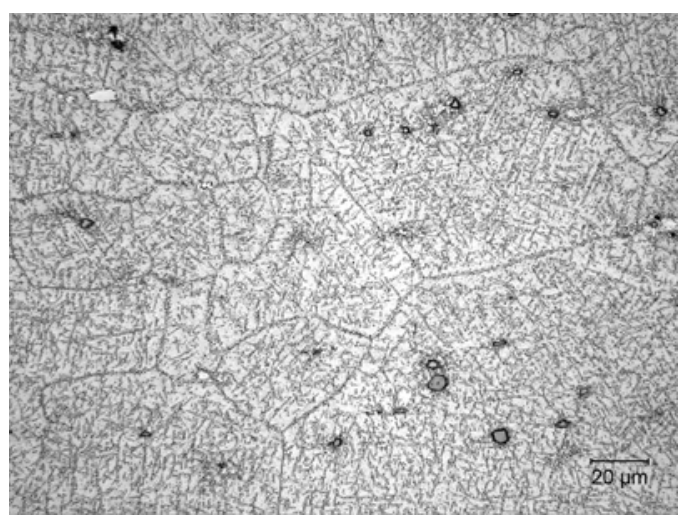

b)

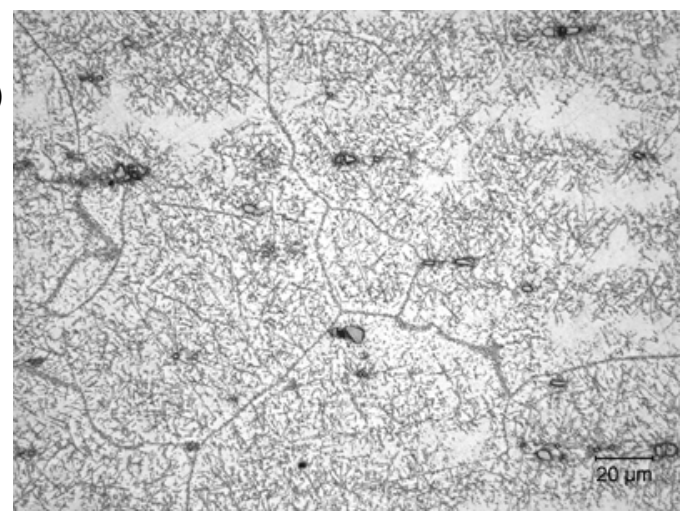

d)

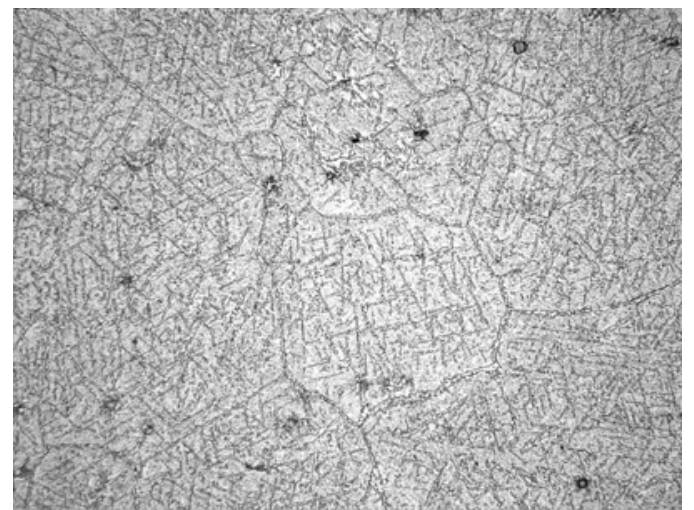

Fig. 5 Optical micrographs of thermally exposed R-41 alloy (1000-hour exposure). a) $1200^{\circ} \mathrm{F}$ $\left.\left(649^{\circ} \mathrm{C}\right), \mathrm{b}\right) 1400^{\circ} \mathrm{F}\left(760^{\circ} \mathrm{C}\right)$, c) $1500^{\circ} \mathrm{F}\left(816^{\circ} \mathrm{C}\right)$, d) $1600^{\circ} \mathrm{F}\left(871^{\circ} \mathrm{C}\right)$. 
a)

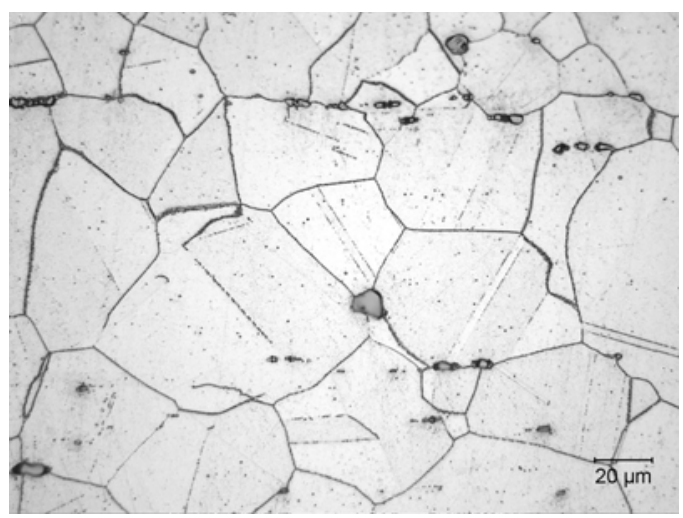

c)

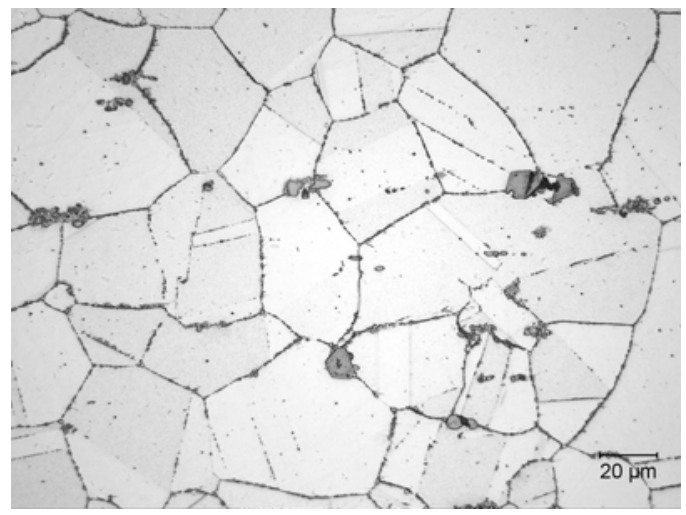

b)

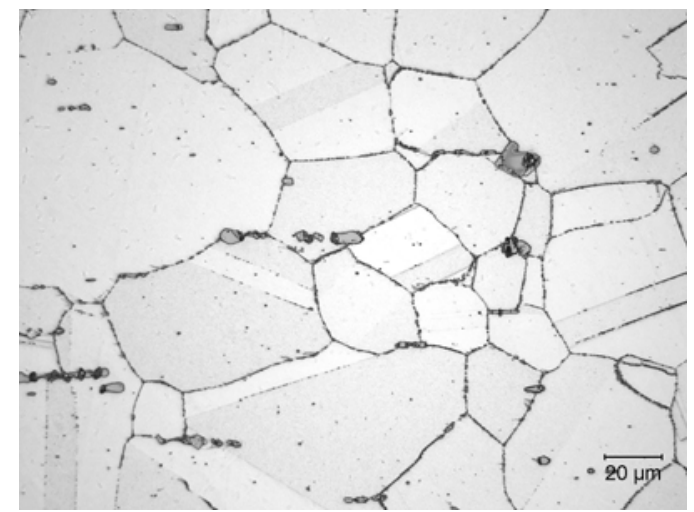

d)

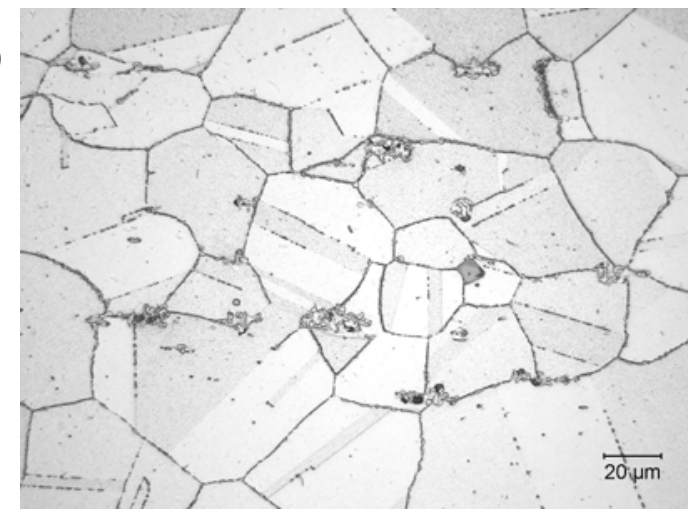

Fig. 6 Optical micrographs of thermally exposed Waspaloy alloy (1000-hour exposure).

a) $1200^{\circ} \mathrm{F}\left(649^{\circ} \mathrm{C}\right)$, b) $1400^{\circ} \mathrm{F}\left(760^{\circ} \mathrm{C}\right)$, c) $1500^{\circ} \mathrm{F}\left(816^{\circ} \mathrm{C}\right)$, d) $1600^{\circ} \mathrm{F}\left(871^{\circ} \mathrm{C}\right)$.

a)

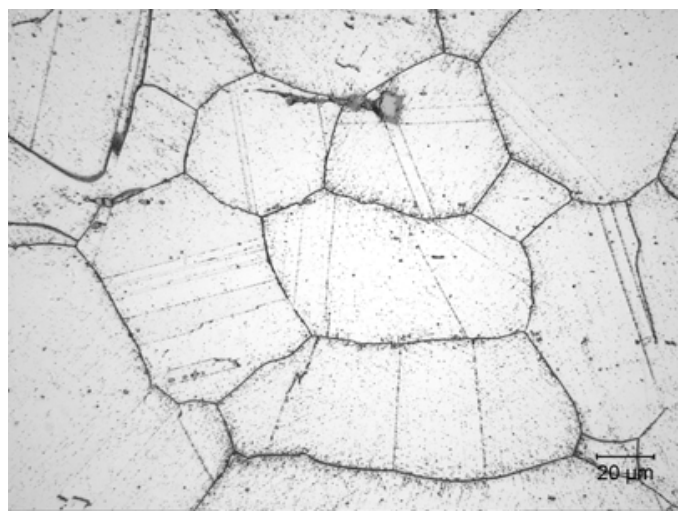

c)

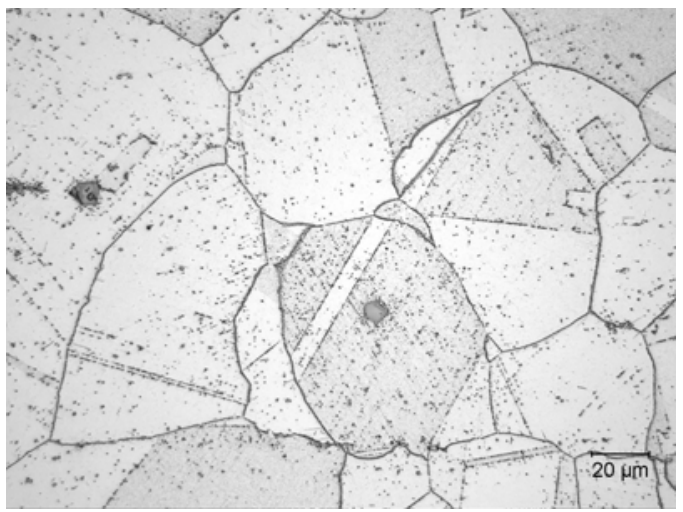

b)

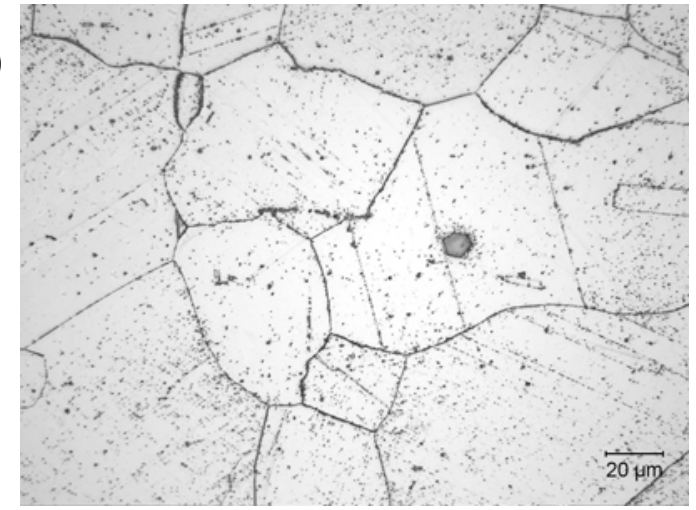

d)

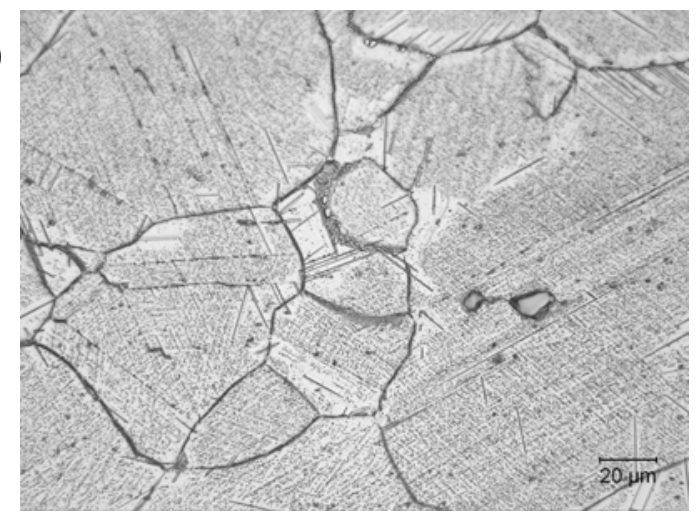

Fig. 7 Optical micrographs of thermally exposed 263 alloy (1000-hour exposure). a) $1200^{\circ} \mathrm{F}$ $\left.\left.\left(649^{\circ} \mathrm{C}\right), \mathrm{b}\right) 1400^{\circ} \mathrm{F}\left(760^{\circ} \mathrm{C}\right), \mathrm{c}\right) 1500^{\circ} \mathrm{F}\left(816^{\circ} \mathrm{C}\right)$, d) $1600^{\circ} \mathrm{F}\left(871^{\circ} \mathrm{C}\right)$. 
a)

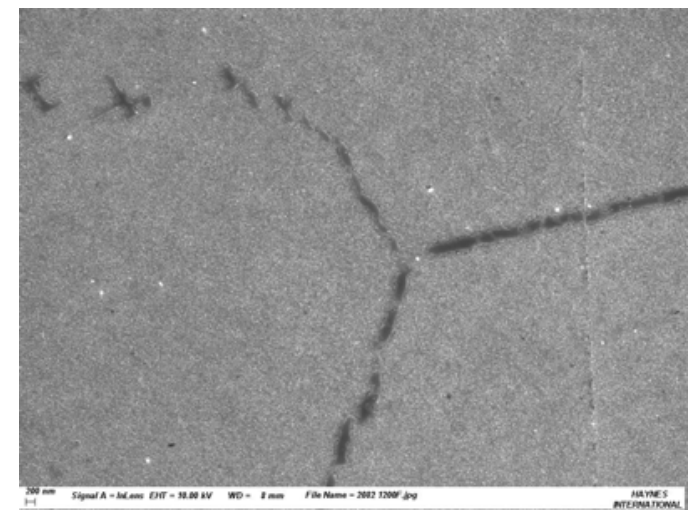

c)

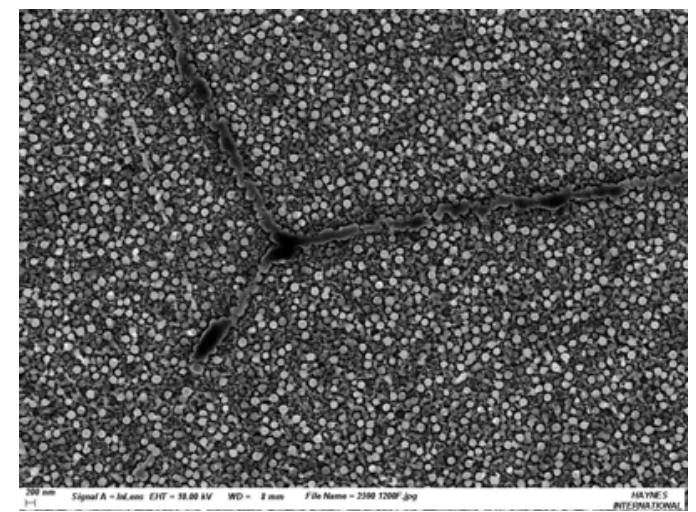

b)

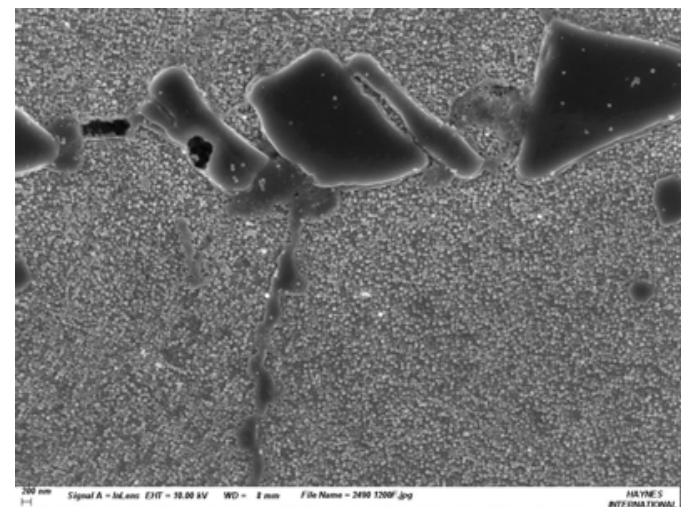

d)

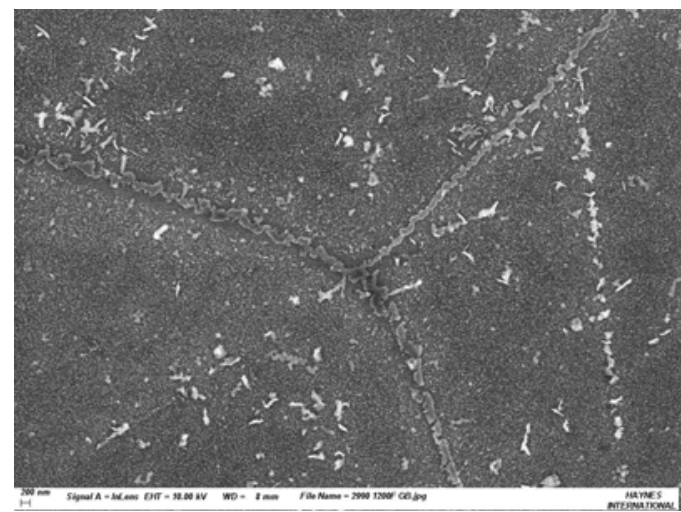

Fig. 8 SEM images (SE) of samples exposed at $1200^{\circ} \mathrm{F}\left(649^{\circ} \mathrm{C}\right) / 1000$-hour. a) 282 alloy, b) R-41 alloy, c) Waspaloy alloy, d) 263 alloy.

a)

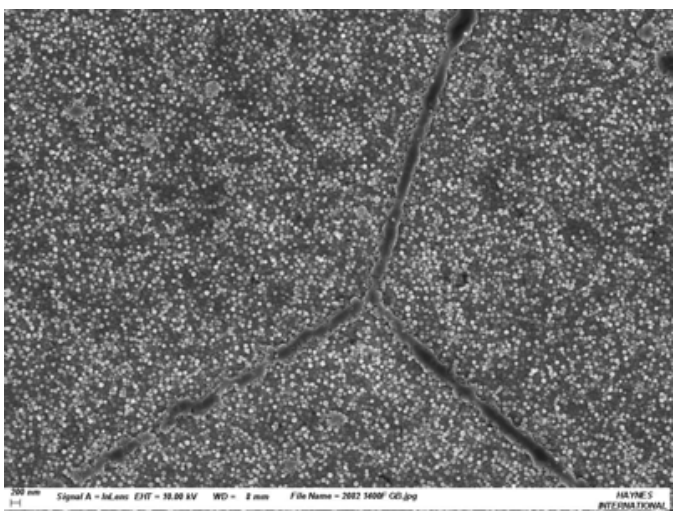

c)

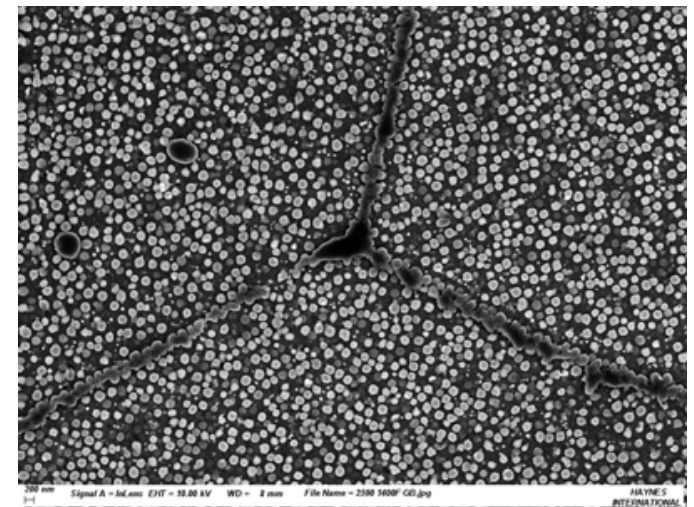

b)

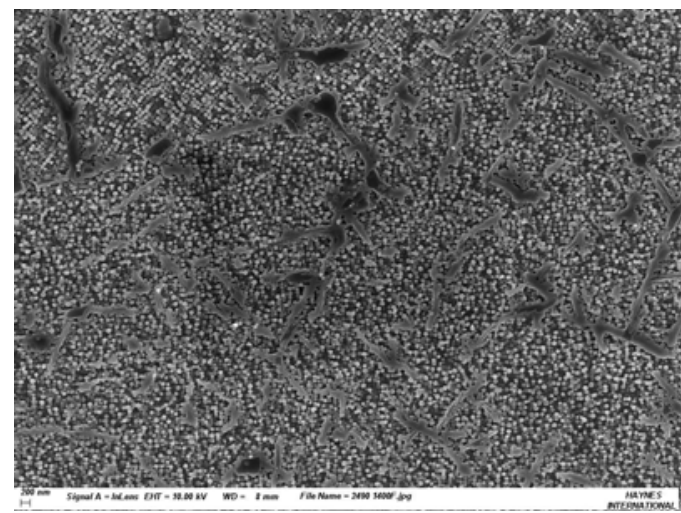

d)

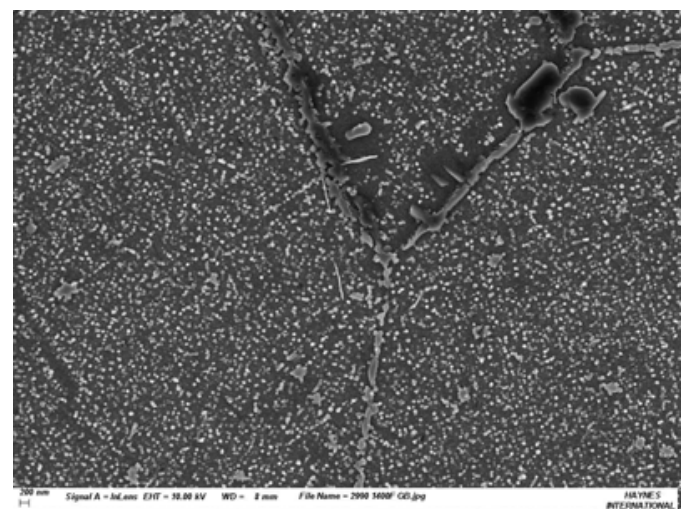

Fig. 9 SEM images (SE) of samples exposed at $1400^{\circ} \mathrm{F}\left(760^{\circ} \mathrm{C}\right) / 1000$-hour. a) 282 alloy, b) R-41 alloy, c) Waspaloy alloy, d) 263 alloy. 
a)

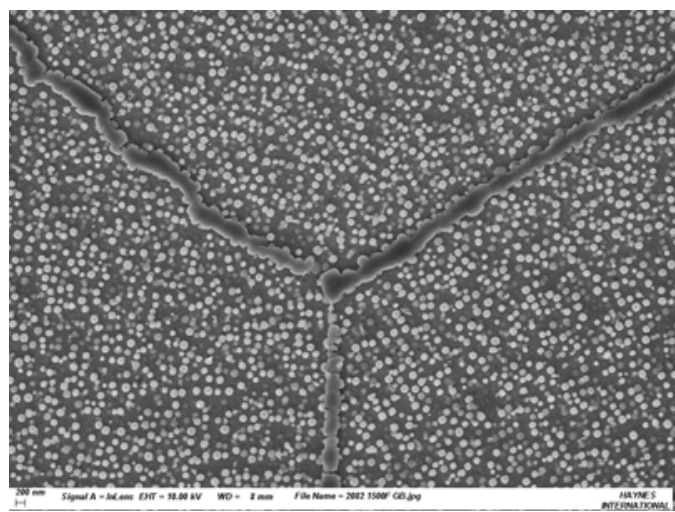

c)

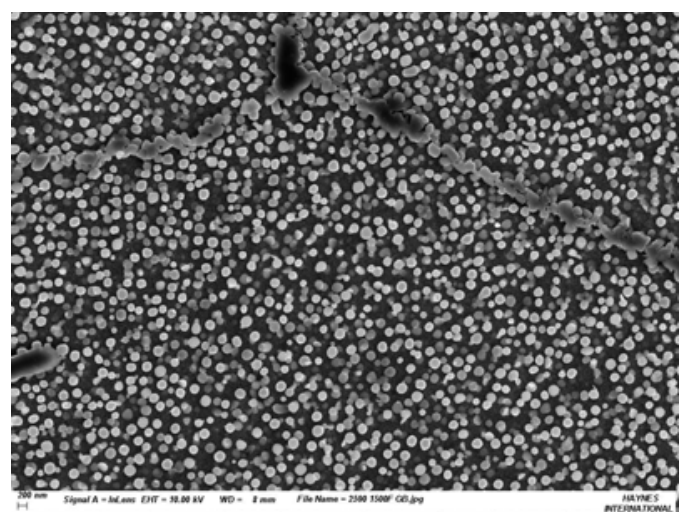

b)

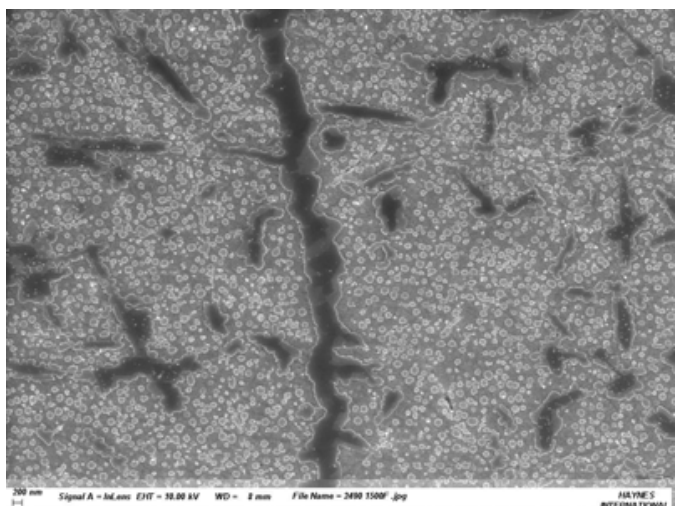

d)

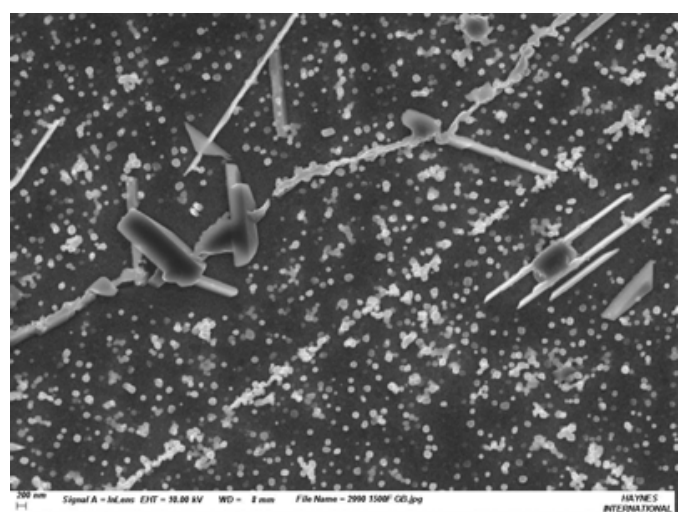

Fig. 10 SEM images (SE) of samples exposed at $1500^{\circ} \mathrm{F}\left(816^{\circ} \mathrm{C}\right) / 1000$-hour. a) 282 alloy, b) R-41 alloy, c) Waspaloy alloy, d) 263 alloy.

a)

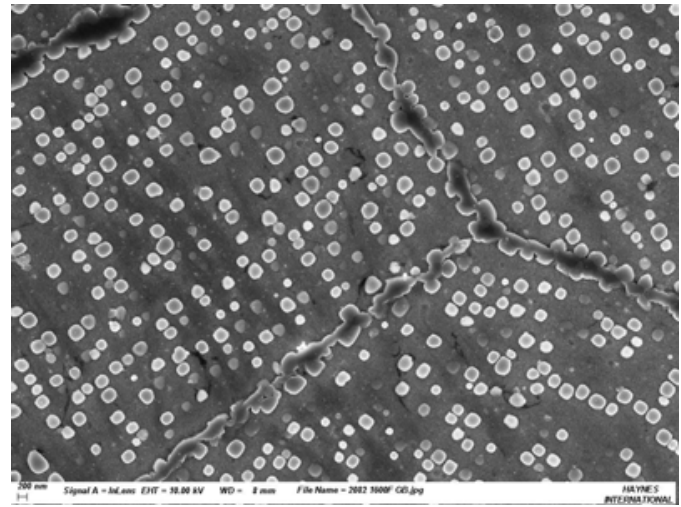

c)

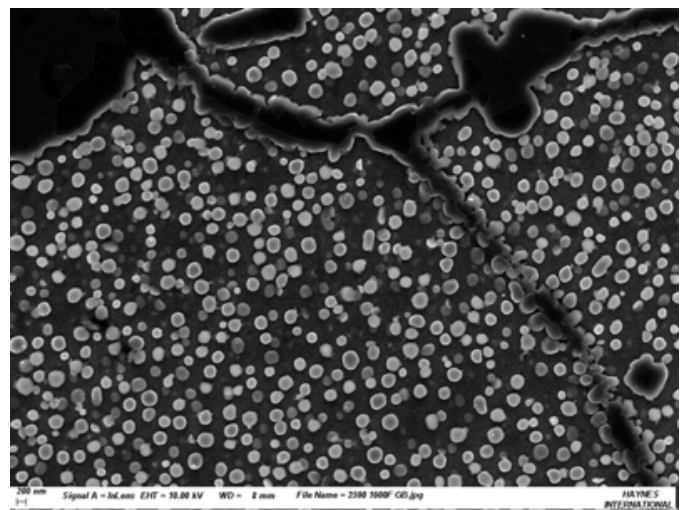

b)

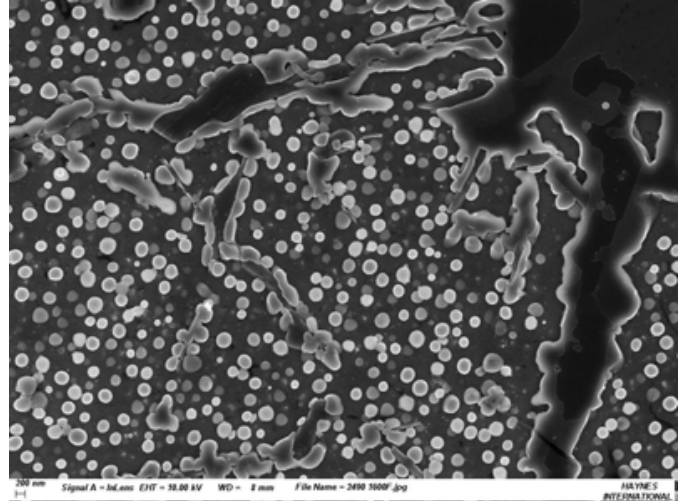

d)

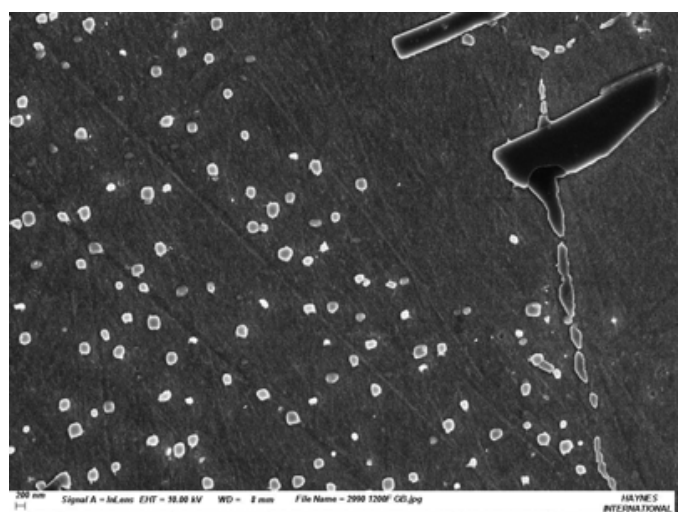

Fig. 11 SEM images (SE) of samples exposed at $1600^{\circ} \mathrm{F}\left(871^{\circ} \mathrm{C}\right) / 1000$-hour. a) 282 alloy, b) R-41 alloy, c) Waspaloy alloy, d) 263 alloy. 
a)

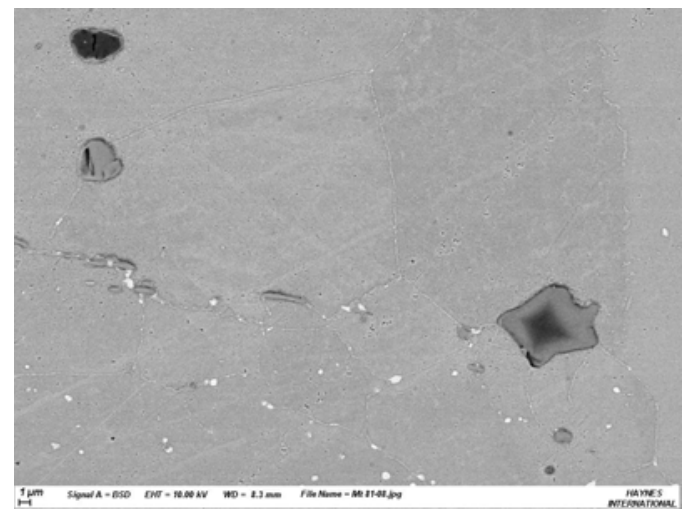

c)

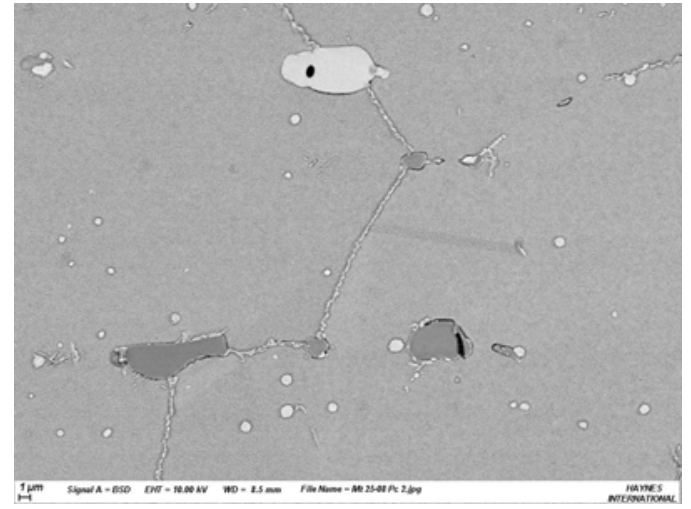

e)

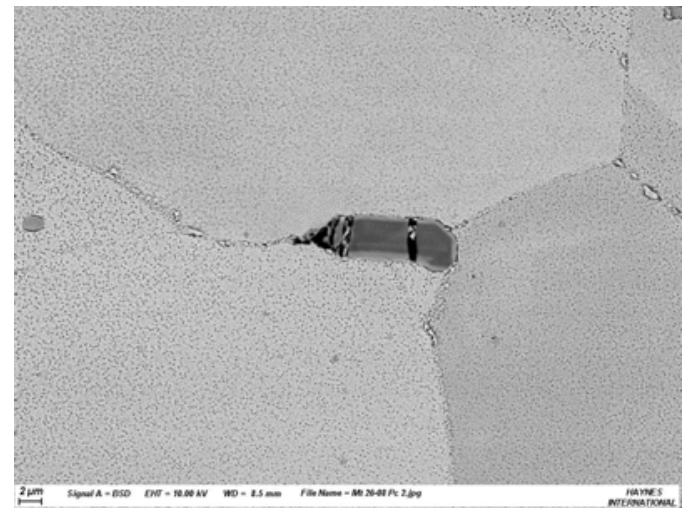

g)

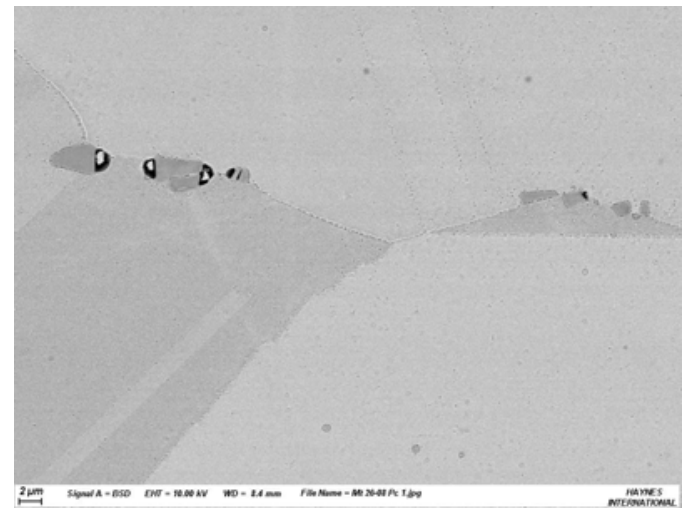

b)

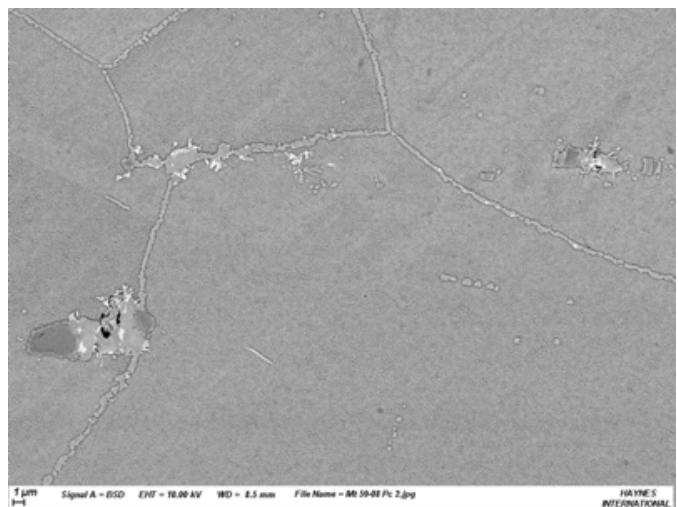

d)

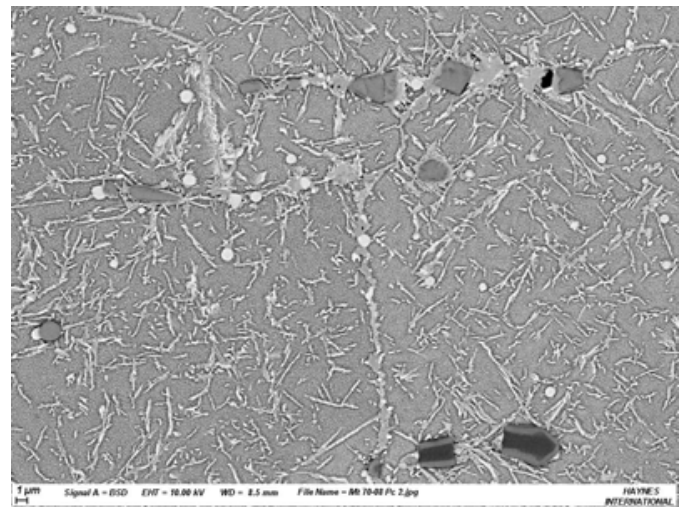

f)

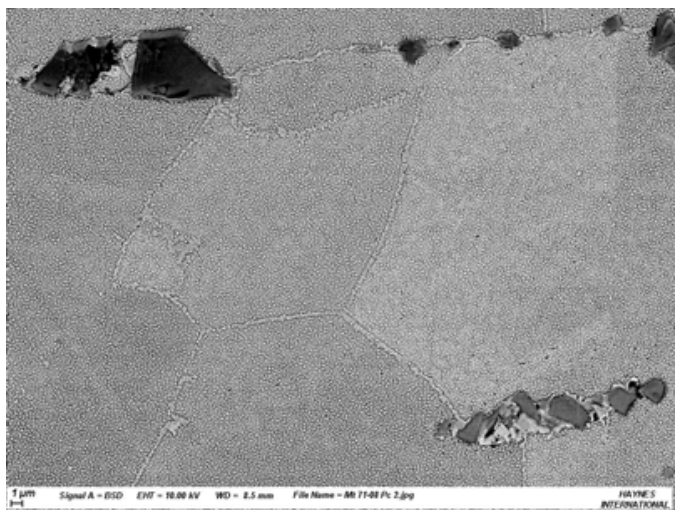

h)

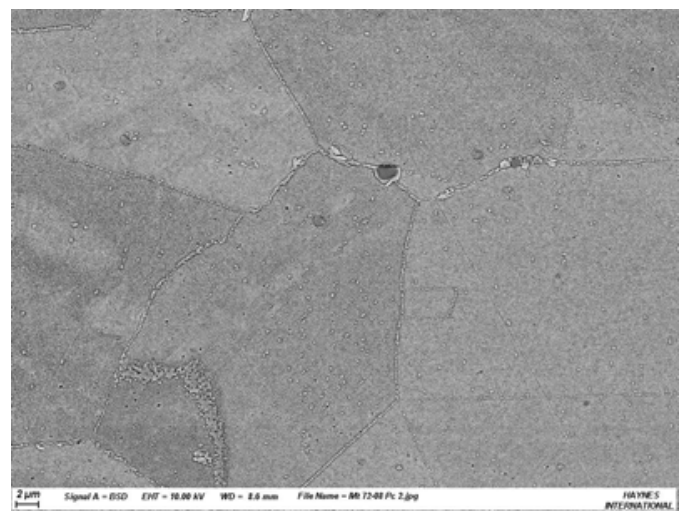

Fig. 12 SEM images (BSE). The images on the left are the as-HT condition and on the right are after the $1400^{\circ} \mathrm{F}\left(760^{\circ} \mathrm{C}\right) / 1000$-hour exposure. a) and b) 282 alloy, c) and d) R-41 alloy, e) and f) Waspaloy alloy, g) and h) 263 alloy. 

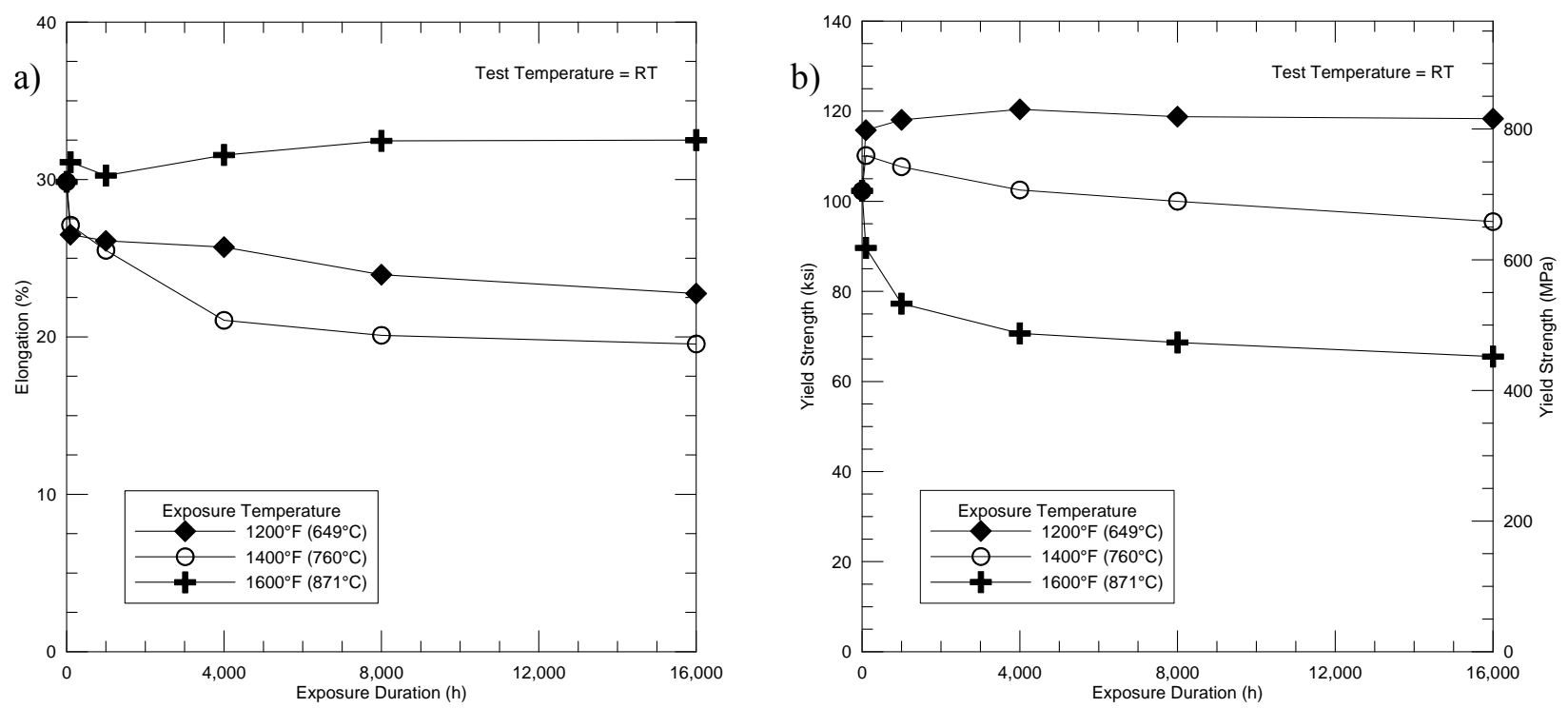

Fig. 13 RT tensile properties of 282 alloy vs. thermal exposure duration. a) elongation, b) yield strength
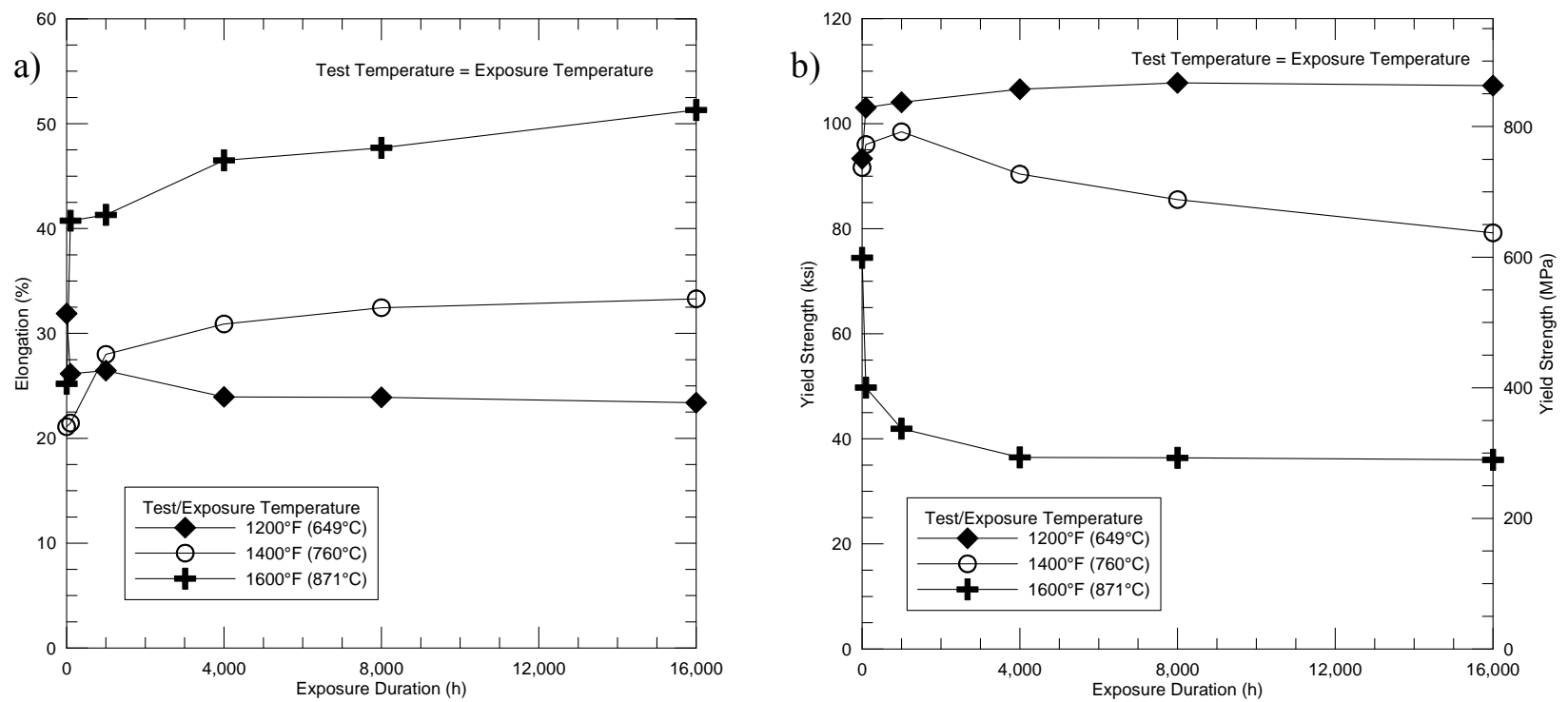

Fig. 14 ET tensile properties of 282 alloy vs. thermal exposure duration. Tensile tests performed at the thermal exposure temperature. a) elongation, b) yield strength

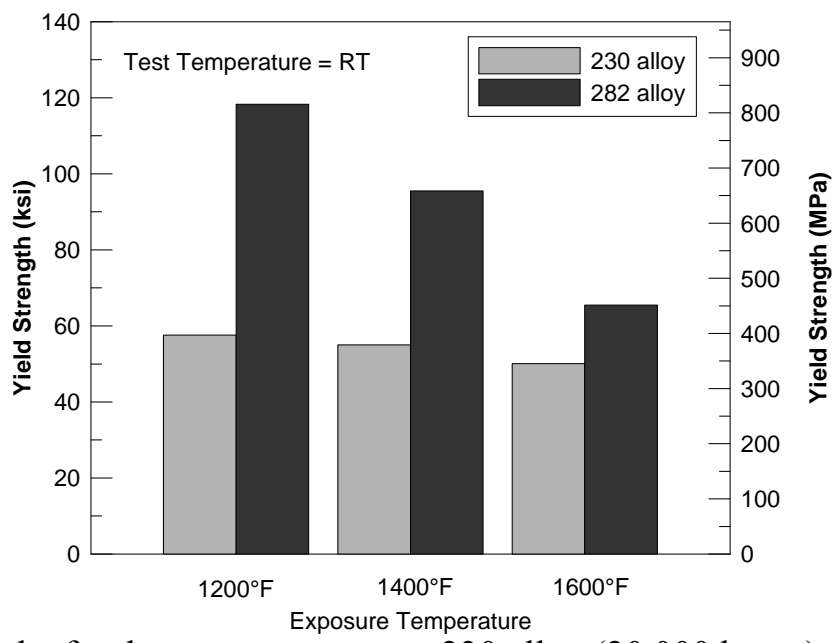

Fig. 15 RT yield strength after long term exposure: 230 alloy (20,000 hours), 282 alloy (16,000 hours). 